\title{
Precise determination of primary cytogenetic abnormalities provides added value for stratification of chronic lymphocytic leukemia patients
}

\author{
P. DVORAK ${ }^{1,2, *}$, D. LYSAK ${ }^{3,4}$, P. VOHRADSKA ${ }^{2}$, I. SUBRT ${ }^{2}$ \\ ${ }^{1}$ Department of Biology, Faculty of Medicine in Pilsen, Charles University in Prague, Pilsen, Czech Republic; ${ }^{2}$ Institute of Medical Genetics, Fac- \\ ulty of Medicine in Pilsen, University Hospital Pilsen, Pilsen, Czech Republic; ${ }^{3}$ Department of Hematology and Oncology, Faculty of Medicine \\ in Pilsen and University Hospital Pilsen, Pilsen, Czech Republic; ${ }^{4}$ Biomedical Center, Faculty of Medicine in Pilsen, Charles University, Pilsen, \\ Czech Republic \\ ${ }^{*}$ Correspondence: Pavel.Dvorak@lfp.cuni.cz
}

Received February 1, 2018 / Accepted April 11, 2018

\begin{abstract}
Cytogenetic analysis has become a standard procedure in the management of newly diagnosed chronic lymphocytic leukemia patients. Prognostic information is reported based on the presence of certain abnormalities and karyotype complexity after conventional karyotyping and/or fluorescence in situ hybridization (FISH). The information on cytogenetic abnormalities occurring in isolation is robust; however, the performance of patients with two or more cytogenetic abnormalities is heterogeneous and information is scarce. This retrospective study analyzed whether information on the precise determination of primary cytogenetic abnormalities can have some added value in terms of risk stratification in chronic lymphocytic leukemia (CLL) patients. The study cohort was 121 patients without the need to start treatment for CLL immediately after diagnosis but had completed initial cytogenetic analysis. Results from conventional karyotyping after stimulation of CLL cells and FISH analysis were combined. Risk stratification based purely on the determination of primary cytogenetic abnormalities was effective in CLL patients, with comparable results in stratification based on the presence of certain abnormalities and karyotype complexity. It is recommended that information on suspected primary abnormalities is included in cytogenetic reports, especially in patients with two or more abnormalities, because this can provide valuable additional information.
\end{abstract}

Key words: primary cytogenetic abnormalities, risk stratification, chronic lymphocytic leukemia

Chronic lymphocytic leukemia (CLL) is one of the most common types in Western countries and has undergone dynamic progress based on intensive basic and clinical research [1]. Cytogenetic and molecular genetic methods have proven very useful and have become widely accessible. Many research discoveries have come into clinical practice and the information from cytogenetic or molecular genetic analyses of pathological lymphocytes has been considered important prognostic and, less frequently, predictive markers for many years [2]. Newer techniques, such as microarraybased comparative genome hybridization (arrayCGH) or next-generation sequencing (NGS), bring a whole-genomic and detailed view on the genome of cancer cells, and this corresponds to the philosophy of personalized medicine. On the other hand, the amount of information earned during each single analysis with these new methods is overwhelming, and without sophisticated computational algorithms it is very difficult to interpret. It is a challenging issue to validate these techniques in routine laboratory practice and suitably incorporate results in the management of CLL diagnostics and treatment $[3,4]$.

The immunoglobulin variable heavy chain $(\operatorname{IgVH})$ mutational status is still considered a main independent genetic prognostic marker [5]. More than $80 \%$ of CLL patients have one or more cytogenetic abnormalities routinely identified by the combination of conventional karyotyping and fluorescence in situ hybridization (FISH) analysis. The most common chromosomal aberrations are deletion of $13 \mathrm{q} 14$ (40-60\% of CLL cases), trisomy 12 (15-30\%), deletion of 11q22-23 (15-20\%), and deletion of 17p13 (5-10\%) [2]. CLL with 13 q14 deletion as a sole abnormality, where deregulation of genes for miRNA is thought to play the major role [6], is generally characterized by a favorable course. Published data supports the concept that chemoimmunotherapy can overcome the prognostic impact of the ATM ('Ataxia Telangiectasia Mutated') gene/11q deletion and indicate this 
deletion as a potential predictive factor for increased benefit by FCR treatment (fludarabine and cyclophosphamide plus rituximab) [5, 7]. Progression-free survival (PFS) of Binet-A patients with trisomy 12 as a sole aberration may be relatively short, but overall survival (OS) appears favorable, particularly with more intensive combined chemotherapy (FC or FCR). Most importantly, TP53 gene/17p deletion has been repeatedly associated with very poor response to chemotherapy (alkylating agents, fludarabine-based approaches), and the shortest survival of around one year in secondary alteration $[5,7]$.

Several recent discoveries in conventional karyotyping and FISH analysis further stress the role of these techniques. Significantly, the discovery that CLL lymphocyte division can be stimulated by culture with the immunostimulatory CpG-oligonucleotide DSP30 plus interleukin 2 has led to improved quality in conventional karyotyping $[8,9]$. The negative prognostic significance of chromosomal translocations in general was one of the first findings revealed by the improved conventional karyotyping [10,11]. Furthermore, adverse clinical and prognostic features correlate positively with abnormal karyotype identified in CLL patients with normal results of standard FISH panel analysis [12]. At diagnosis, patients with a higher number of losses in 13 q14 as the sole cytogenetic aberration identified by FISH and ranging from 60 to $90 \%$ in different studies, displayed repeatedly short OS and time to first treatment (TTFT) [13-16]. Similarly, the negative influence of ATM/11q22 deletion on prognosis, when involving the vast majority of the CLL clone, has been described $[17,18]$. More information is also appearing about less frequent abnormalities associated with CLL, such as the worse outcome attributed to $I G H$ rearrangements $[19,20]$.

Notably, pathological clones of approximately half CLL patients harbor more than one cytogenetic abnormality; however, the relationships between the abnormalities are not always sufficiently stressed. Moreover, specific information on heterogeneity in disease progression in patients with more than one cytogenetic abnormality is limited. This article therefore implements the theory that precise determination of primary cytogenetic abnormalities in CLL clones with several abnormalities can add important information for patient risk stratification.

\section{Patients and methods}

Patient samples. The whole cohort consisted of 146 unselected patients who were consecutively diagnosed with CLL at the Hemato-oncology department of the University Hospital Pilsen between 2009 and 2012. 121 of the 146 patients were selected to constitute the study cohort which entered further analyses. The following criteria were applied to select the study cohort: 1) Rai stage 0,1 or 2 without the need to start treatment for CLL immediately after the diagnosis, 2) completed cytogenetic analysis at the time of
CLL diagnosis (conventional karyotyping after stimulation of CLL cells with DSP30/IL2 as well as FISH analysis with a standard panel of probes), and 3) minimum of two years' follow-up in patients who were alive at the time of patient selection. The diagnosis and treatment of CLL was established according to the guidelines of the International Workshop on Chronic Lymphocytic Leukemia/National Cancer Institute (IWCLL/NCI) [21]. The baseline clinical characteristics of the selected patients are summarized in the first paragraph of the Results and in Table 1. Treatment for CLL comprised different chemo-immunotherapy regimens disclosed for individual patients, and other clinical data is in Table S1. The study was conducted in accordance with the Declaration of Helsinki and approved by the review board of our institution.

Conventional karyotyping and FISH analysis. Cells extracted from bone marrow samples obtained at the time of diagnosis were analyzed for all patients by cytogenetic methods. Stimulation of CLL cells using CpG-oligonucleotide DSP30 (2 lmol/l Tib-MolBiol Berlin, Germany) plus IL2 (100 U/ml Stem Cell Technologies, Milan, Italy), as described previously $[8,9]$, was performed during 72 -h cultivation. Chromosome preparation and staining (G-banding) was done according to standard protocols. Cytogenetic analyses followed the recommended guidelines for clinical cytogenetics - Association of Clinical Cytogeneticists (ACC) and National External Quality Assessment Schemes (UK NEQAS). Chromosome abnormalities were classified according to the International System for Human Cytogenetic Nomenclature (ISCN) [22].

Interphase and metaphase FISH analysis was conducted on the same bone marrow samples as conventional karyotyping (Vysis/Abbott Co, Downers Grove, IL, USA; Kreatech, Amsterdam, NL). Commercially available probes for the following chromosomal regions were applied in the basic FISH panel: 13q14 (D13S319 or DLEU1), 12q13 (D12Z3), 11q22 (ATM), 17p13 (TP53), 6p11.1-q11.1(D6Z1), and 6q21(SEC63).

Statistical analysis. The primary endpoint, TTFT, was defined as the interval between the date of diagnosis and the date of initiation of first CLL treatment. The KaplanMeier method estimated the probabilities of TTFT, and subgroup comparisons were made via the log-rank test. Data was tested by predominantly non-parametric statistics (the Mann-Whitney $U$ and Kruskal-Wallis tests). The $p$-value was considered significant when $\leq 0.05$. All statistical analyses were conducted using Statistica software (Statsoft, Czech Republic) and the freely available PAST statistical software package (http://palaeo-electronica.org/2001_1/ past/issue1_01.htm).

\section{Results}

The study cohort of 121 treatment new patients with completed cytogenetics (G-banding and FISH) was chosen 
Table 1. Overall characteristics of the study cohort.

\begin{tabular}{lc}
\hline Patients & N/y./m. \\
\hline All & 121 \\
Males & 77 \\
Females & 44 \\
Median age at dg. (y.) & 62 \\
(Range, y.) & $(33-79)$ \\
Treated for other malignancy & 3 \\
Rai 0 status & 41 \\
Rai 1 & 61 \\
Rai 2 & 19 \\
Median follow-up (m.) & 63 \\
(Range, m.; min. 24 m. in p. alive) & $4-119$ \\
\hline
\end{tabular}

Abbreviations: dg., diagnosis; m., months; min., minimum; p., patients; y., years;

from 146 unselected CLL patients. It consisted of 77 males and 44 females; the median age at diagnosis was 62 years (range 33-79 years) and the median follow-up 63 months (range 4-119 months), with a minimum of two years' followup in patients who were alive at the time of patient selection for the study. There were 41, 61 and 19 Rai stage 0, 1 and 2 patients, respectively (summarized with other patient details in Table 1). Two different concepts were applied to divide patients into specific cytogenetic subgroups. The first concept of cytogenetic subgroup selection was based on the determination of primary cytogenetic abnormalities. The second was based on the presence of certain cytogenetic abnormalities and karyotype complexity, in line with the conventional method of CLL patient division currently used in cytogenetic laboratories. The comparison of these two methods for CLL patient stratification was the main objective of the present study.

Determination of the primary cytogenetic abnormality. The following three steps were applied to determine the primary abnormality: any abnormality found as a sole abnormality in a clone revealed during the conventional karyotyping and present in the highest percentage of interphase nuclei during the parallel FISH analysis, was considered a primary cytogenetic abnormality; if this was not found, the abnormality seen in the highest percentage of interphase nuclei by FISH was considered primary, and finally, where the first two steps did not end with conclusions on primary abnormalities, the results of FISH analysis of metaphase nuclei were considered.

Stratification according to primary cytogenetic abnormalities - whole cohort. According to primary cytogenetic abnormalities, patients were divided into eight main categories: 1) 13q14 deletion ( $\mathrm{N}=48 ; 40 \%), 2) 11 \mathrm{q} 22 / \mathrm{ATM}$ deletion $(\mathrm{N}=11 ; 9 \%), 3)$ Trisomy $12(\mathrm{~N}=15 ; 12 \%), 4) 17 \mathrm{p} 13 / \mathrm{TP} 53$ deletion $(\mathrm{N}=4 ; 3 \%), 5) 6 \mathrm{q} 21 / \mathrm{SEC} 63$ deletion $(\mathrm{N}=5 ; 4 \%), 6)$ Normal - without cytogenetic abnormality ( $\mathrm{N}=20 ; 17 \%), 7)$ Other primary abnormality $(\mathrm{N}=11 ; 9 \%)$, and 8 ) ambiguous primary abnormality $(\mathrm{N}=7 ; 6 \%)$. Only 7 patients (including 3 with complex karyotype) out of the 121 (6\%), where the application of the above stated rules did not end with decision on the primary abnormality, were sorted into main category 8); Ambiguous primary abnormality. Three patients, in whom the percentage of pathological cells found by cytogenetic analyses was considerably lower than the percentage of cells with a typical CLL immunophenotype reported by FACS (fluorescence-activated cell sorting) analyses, were considered to have primarily normal karyotype and were appointed to main category 6); Normal - without cytogenetic abnormality. Table S1 in the Supporting information shows all cytogenetic and clinical data for the whole study cohort, including assignment to sub-groups based on primary abnormalities.

The following median time to first treatments (TTFTs) were calculated for the main categories (from the shortest to the longest): 4 months (m.) - Del(11q), 9 m. - Del(17p), 11 m. - Ambiguous, 13 m. - $\operatorname{Del}(6 \mathrm{q}), 14$ m. - Trisomy 12, 17 m. - Del(13q), 17 m. - Other abnormality, 26 m. - Normal. Percentages of patients who started treatment for CLL in less than 2 years from diagnosis from all patients in the subgroup were (from the highest to the lowest): $100 \%-\operatorname{Del}(17 \mathrm{p}), 100 \%$ - Del(6q), 82\% - Del(11q), 48\% - Del(13q), 33\% - Trisomy 12, 29\% - Ambiguous, 27\% - Other abnormality, 25\% Normal. Percentages of patients who achieved complete remission (CR) after first line therapy from all patients with treatment in the subgroup were (from the lowest to the highest): $17 \%$ - Other abnormality, 25\% - Del(17p), 63\% Trisomy 12, 64\% - Normal, 73\% - Del(11q), 80\% - Del(6q), $86 \%$ - Del(13q), 100\% - Ambiguous. Percentages of patients who died during the follow-up of the study, from all patients in the subgroup, were (from the highest to the lowest): $100 \%$ - Del(17p), 36\% - Del(11q), 29\% - Ambiguous, 20\% - Del(6q), 20\% - Trisomy 12, 15\% - Normal, 9\% - Other abnormality, $4 \%$ - Del(13q). Results of the stratification are summarized in Table 2.

Stratification according to types of abnormalities and karyotype complexity - whole cohort. According to types of cytogenetic abnormalities and karyotype complexity, patients were divided into nine main categories: 1) Sole 13q14 deletion ( $\mathrm{N}=28 ; 23 \%), 2$ ) Sole 11q22/ATM deletion $(\mathrm{N}=4 ; 3 \%), 3)$ Sole trisomy $12(\mathrm{~N}=8 ; 7 \%), 4)$ Sole $17 \mathrm{p} 13 / \mathrm{TP} 53$ deletion $(\mathrm{N}=0), 5)$ Sole 6q21/SEC63 deletion $(\mathrm{N}=4 ; 3 \%), 6)$ Normal - without cytogenetic abnormality $(\mathrm{N}=17 ; 14 \%), 7)$ Sole other abnormality ( $\mathrm{N}=5 ; 4 \%), 8)$ Two cytogenetic abnormalities ( $\mathrm{N}=28$; 23\%), and 9) Three and more cytogenetic abnormalities complex karyotype $(\mathrm{N}=27 ; 22 \%)$. Results from conventional karyotyping (G-banding) and FISH analyses were combined. Where derivative chromosomes were recorded according to the ISCN, each derivative chromosome was counted as one cytogenetic abnormality. Similarly, bi-allelic deletion of 13 q14 was evaluated as two cytogenetic abnormalities. On the other hand, a karyotype with 49 chromosomes and the trisomies of 12,18 , and 19 , which is recognized as a separate 
Table 2. Characteristics of cytogenetic subgroups based on the determination of primary abnormalities - whole cohort.

\begin{tabular}{|c|c|c|c|c|c|c|c|c|}
\hline Patients in subgroups & $\operatorname{Del}(11 q)$ & $\operatorname{Del}(17 p)$ & Ambiguous & $\operatorname{Del}(6 q)$ & Trisomy 12 & $\operatorname{Del}(13 q)$ & Other abn & Normal \\
\hline $\mathrm{N}$ & 11 & 4 & 7 & 5 & 15 & 48 & 11 & 20 \\
\hline$\%$ of all & 9 & 3 & 6 & 4 & 12 & 40 & 9 & 17 \\
\hline Males (N) & 6 & 4 & 5 & 5 & 7 & 30 & 5 & 15 \\
\hline Females (N) & 5 & 0 & 2 & 0 & 8 & 18 & 6 & 5 \\
\hline Median age at dg. (y.) & 67 & 65 & 62 & 62 & 61 & 62 & 62 & 62 \\
\hline Treatment for other malignancy $(\mathrm{N})$ & 1 & 0 & 0 & 0 & 1 & 0 & 0 & 1 \\
\hline Rai 0 status $(\mathrm{N})$ & 0 & 0 & 2 & 2 & 7 & 16 & 5 & 9 \\
\hline Rai 1 & 7 & 4 & 4 & 2 & 8 & 22 & 5 & 9 \\
\hline Rai 2 & 4 & 0 & 1 & 1 & 0 & 10 & 1 & 2 \\
\hline Median follow-up (m.) & 51 & 35 & 57 & 64 & 73 & 77 & 58 & 55 \\
\hline Treatment for CLL (N) & 11 & 4 & 3 & 5 & 8 & 36 & 6 & 11 \\
\hline$\%$ of p. with treatment out of all p. in the subg. & 100 & 100 & 43 & 100 & 53 & 75 & 55 & 55 \\
\hline Median TTFT (m.) & 4 & 9 & 11 & 13 & 14 & 17 & 17 & 26 \\
\hline Treatment started in less than 2 y. after dg. (N) & 9 & 4 & 2 & 5 & 5 & 23 & 3 & 5 \\
\hline$\%$ of p. with tr. in less than 2 y. out of all p. in the subg. & 82 & 100 & 29 & 100 & 33 & 48 & 27 & 25 \\
\hline CR after 1. line therapy $(\mathrm{N})$ & 8 & 1 & 3 & 4 & 5 & 31 & 1 & 7 \\
\hline$\%$ of p. with CR out of all p. with tr. in the subg. & 73 & 25 & 100 & 80 & 63 & 86 & 17 & 64 \\
\hline $\mathrm{PR}$ after 1 . line therapy $(\mathrm{N})$ & 1 & 2 & 0 & 1 & 3 & 5 & 5 & 3 \\
\hline$\%$ of p. with PR out of all p. with tr. in the subg. & 9 & 50 & 0 & 20 & 38 & 14 & 83 & 27 \\
\hline Relaps/progression $(\mathrm{N})$ & 5 & 3 & 2 & 4 & 6 & 18 & 4 & 5 \\
\hline$\%$ of $\mathrm{p}$. with relaps/progression out of all p. with tr. in the subg. & 45 & 75 & 67 & 80 & 75 & 50 & 67 & 45 \\
\hline Median TTFP (m.) & 18 & 21 & 21 & 33 & 27 & 27 & 17 & 18 \\
\hline $\operatorname{Died}(\mathrm{N})$ & 4 & 4 & 2 & 1 & 3 & 2 & 1 & 3 \\
\hline$\%$ of p. died out of all p. in the subg. & 36 & 100 & 29 & 20 & 20 & 4 & 9 & 15 \\
\hline Died - median survival (m.) & 40 & 35 & 67 & 60 & 65 & 53 & 76 & 50 \\
\hline Died for CLL $(\mathrm{N})$ & 2 & 2 & 0 & 0 & 2 & 0 & 1 & 2 \\
\hline$\%$ of p. died for CLL out of all p. in the subg. & 18 & 50 & 0 & 0 & 13 & 0 & 9 & 10 \\
\hline
\end{tabular}

Abbreviations: CR, complete remission; dg., diagnosis; m., months; p., patients; PR, partial remission; subg., subgroup; tr., treatment; TTFP, time to first relaps/progression; TTFT, time to first treatment; y., years

sub-entity, was counted as one cytogenetic abnormality. To determine the total number of cytogenetic abnormalities in the presence of several unrelated pathological clones, the number of abnormalities from the individual clones was computed. Notably, there was no patient with sole 17p13/ TP53 deletion in the study cohort.

The following median TTFTs were calculated for the remainder (from the shortest to the longest): $2 \mathrm{~m}$. - Sole other abnormality, $4 \mathrm{~m}$. - Sole $\operatorname{del}(1 \mathrm{qq}), 6 \mathrm{~m}$. - Minimum three abnormalities, $14 \mathrm{~m}$. - Two abnormalities, $15 \mathrm{~m}$. - Sole $\operatorname{del}(6 q), 20$ m. - Sole del(13q), 26 m. - Normal, 37 m. - Sole trisomy 12 . The percentages of patients who started treatment for CLL in less than 2 years from diagnosis, out of all patients in the subgroup, were (from the highest to the lowest): $100 \%$ - Sole del(6q), 74\% - Minimum three abnormalities, 50\% Sole del(11q), 43\% - Two abnormalities, $40 \%$ - Sole other abnormality, 36\% - Sole del(13q), 29\% - Normal, 13\% Sole trisomy 12 . The percentages of patients who achieved CR after first line therapy from all patients with treatment in the subgroup were (from the lowest to the highest): $0 \%$ Sole other abnormality, 33\% - Sole del(11q), 64\% - Normal, $71 \%$ - Minimum three abnormalities, $75 \%$ - Sole $\operatorname{del}(6 \mathrm{q})$,
$75 \%$ - Sole trisomy 12, 76\% - Two abnormalities, $89 \%$ - Sole $\operatorname{del}(13 q)$. The percentages of patients who died during the follow-up of the study from all patients in the subgroup were (from the highest to the lowest): 50\% - Sole $\operatorname{del}(11 \mathrm{q}), 30 \%-$ Minimum three abnormalities, 25\% - Sole trisomy 12, 20\% - Sole other abnormality, 18\% - Normal, 11\% - Two abnormalities, 4\% - Sole del(13q), 0\% - Sole del(6q). A summary of the stratification is shown in Table 3.

There were 5 patients assigned to the main category 7) 'sole, other abnormality' which presented with the shortest TTFT. Three of the patients started treatment for CLL during study, with extremely fast TTFT in two (1 and 2 months). The karyotypes of these two patients were: 46,XY,t $(14 ; 17)$ (q24;q25)[3]/46,XY [17] (without translocation in IGH gene) and 46,XX,der(10)t(2;10)(?p12;q26)[16]/46,XX[4] (duplication of $2 \mathrm{p}$ ), respectively.

Comparison of stratification according to primary abnormalities versus type and complexity - whole cohort. The comparison of the two methods for CLL patient stratification was based on the four selected characteristics Median TTFT, Percentages of patients with treatment in less than 2 years, Percentages of patients with CR, and Percent- 
Table 3. Characteristics of cytogenetic subgroups based on the presence of certain abnormalities and karyotype complexity - whole cohort.

\begin{tabular}{|c|c|c|c|c|c|c|c|c|c|}
\hline Patients in subgroups & $\begin{array}{c}\text { Sole } \\
\text { other }\end{array}$ & $\begin{array}{c}\text { Sole } \\
\operatorname{del}(11 \mathrm{q})\end{array}$ & $\begin{array}{c}\text { Min three } \\
\text { abn overall }\end{array}$ & $\begin{array}{c}\text { Two abn } \\
\text { overall }\end{array}$ & $\begin{array}{c}\text { Sole } \\
\operatorname{del}(6 \mathrm{q})\end{array}$ & $\begin{array}{c}\text { Sole } \\
\operatorname{del}(13 q)\end{array}$ & Normal & $\begin{array}{l}\text { Sole tri- } \\
\text { somy } 12\end{array}$ & $\begin{array}{c}\text { Sole } \\
\operatorname{del}(17 p)\end{array}$ \\
\hline $\mathrm{N}$ & 5 & 4 & 27 & 28 & 4 & 28 & 17 & 8 & 0 \\
\hline$\%$ of all & 4 & 3 & 22 & 23 & 3 & 23 & 14 & 7 & - \\
\hline Males (N) & 2 & 2 & 13 & 21 & 4 & 17 & 14 & 4 & - \\
\hline Females $(\mathrm{N})$ & 3 & 2 & 14 & 7 & 0 & 11 & 3 & 4 & - \\
\hline Median age at dg. (y.) & 74 & 66 & 65 & 62 & 61 & 61 & 62 & 62 & - \\
\hline Treatment for other malignancy $(\mathrm{N})$ & 0 & 1 & 0 & 0 & 0 & 1 & 0 & 1 & - \\
\hline Rai 0 status $(\mathrm{N})$ & 2 & 0 & 4 & 11 & 2 & 10 & 8 & 4 & - \\
\hline Rai 1 & 2 & 4 & 14 & 14 & 2 & 14 & 7 & 4 & - \\
\hline Rai 2 & 1 & 0 & 9 & 3 & 0 & 4 & 2 & 0 & - \\
\hline Median follow-up (m.) & 62 & 56 & 66 & 58 & 68 & 77 & 55 & 70 & - \\
\hline Treatment for CLL (N) & 3 & 3 & 24 & 17 & 4 & 18 & 11 & 4 & - \\
\hline$\%$ of p. with treatment out of all p. in the subg. & 60 & 75 & 89 & 61 & 100 & 64 & 65 & 50 & - \\
\hline Median TTFT (m.) & 2 & 4 & 6 & 14 & 15 & 20 & 26 & 37 & - \\
\hline Treatment started in less than 2 y. after dg. $(\mathrm{N})$ & 2 & 2 & 20 & 12 & 4 & 10 & 5 & 1 & - \\
\hline$\%$ of p. with tr. in less than 2 y. out of all p. in the subg. & 40 & 50 & 74 & 43 & 100 & 36 & 29 & 13 & - \\
\hline $\mathrm{CR}$ after 1 . line therapy $(\mathrm{N})$ & 0 & 1 & 17 & 13 & 3 & 16 & 7 & 3 & - \\
\hline$\%$ of p. with CR out of all p. with tr. in the subg. & $\mathbf{0}$ & 33 & 71 & 76 & 75 & 89 & 64 & 75 & - \\
\hline $\mathrm{PR}$ after 1. line therapy $(\mathrm{N})$ & 3 & 0 & 6 & 4 & 1 & 2 & 3 & 1 & - \\
\hline$\%$ of p. with PR out of all p. with tr. in the subg. & 100 & 0 & 25 & 24 & 25 & 11 & 27 & 25 & - \\
\hline Relaps/progression $(\mathrm{N})$ & 2 & 0 & 15 & 11 & 3 & 8 & 5 & 3 & - \\
\hline$\%$ of p. with relaps/progression out of all p. with tr. in the subg. & 67 & 0 & 63 & 65 & 75 & 44 & 45 & 75 & - \\
\hline Median TTFP (m.) & 26 & - & 23 & 23 & 38 & 30 & 18 & 24 & - \\
\hline $\operatorname{Died}(\mathrm{N})$ & 1 & 2 & 8 & 3 & 0 & 1 & 3 & 2 & - \\
\hline$\%$ of p. died out of all p. in the subg. & 20 & 50 & 30 & 11 & $\mathbf{0}$ & 4 & 18 & 25 & - \\
\hline Died - median survival (m.) & 76 & 34 & 35 & 59 & - & 102 & 50 & 71 & - \\
\hline Died for CLL $(\mathrm{N})$ & 1 & 1 & 3 & 1 & 0 & 0 & 2 & 1 & - \\
\hline$\%$ of p. died for CLL out of all p. in the subg. & 20 & 25 & 11 & 4 & 0 & 0 & 12 & 13 & - \\
\hline
\end{tabular}

Abbreviations: abn, abnormality; CR, complete remission; dg., diagnosis; m., months; p., patients; PR, partial remission; subg., subgroup; tr., treatment;

TTFP, time to first relaps/progression; TTFT, time to first treatment; y., years

Table 4. Comparison of two methods for CLL patients'stratification based on cytogenetics - whole cohort.

\begin{tabular}{|c|c|c|c|c|c|c|c|c|c|}
\hline I. Primary abn. & $\operatorname{Del}(17 p)$ & $\operatorname{Del}(11 q)$ & $\operatorname{Del}(6 q)$ & $\begin{array}{l}\text { Ambi- } \\
\text { guous }\end{array}$ & Trisomy 12 & Other abn. & $\operatorname{Del}(13 q)$ & Normal & \\
\hline Risk & \multicolumn{2}{|c|}{ High } & \multicolumn{3}{|c|}{ Intermediate } & \multicolumn{3}{|c|}{ Low } & \\
\hline Median TTFT (m.) & 2. & 1. & 4. & 3. & 5. & $6 .-7$. & $6 .-7$ & 8. & \\
\hline $\begin{array}{l}\% \text { of p. with tr. in less than } 2 \\
\text { y. out of all p. in the subg. }\end{array}$ & 1.-2. & 3. & 1.-2. & 6. & 5. & 7. & 4. & 8. & \\
\hline $\begin{array}{l}\% \text { of p. with CR out of all p. } \\
\text { with tr. in the subg. }\end{array}$ & 2. & 5. & 6. & 8. & 3. & 1. & 7. & 4. & \\
\hline $\begin{array}{l}\% \text { of p. died out of all p. in } \\
\text { the subg. }\end{array}$ & 1. & 2. & 4. -5 . & 3. & 4. -5 . & 7. & 8. & 6. & \\
\hline Median Value & 1.8 & 2.5 & 4.3 & 4.5 & 4.8 & 6.8 & 6.8 & 7 & \\
\hline $\begin{array}{l}\text { II. Type of abn. and kar. } \\
\text { complexity }\end{array}$ & $\begin{array}{c}\text { Sole } \\
\operatorname{del}(11 q)\end{array}$ & $\begin{array}{l}\text { Sole } \\
\text { other }\end{array}$ & $\begin{array}{l}\text { Min three } \\
\text { abn. overall }\end{array}$ & $\begin{array}{l}\text { Two abn. } \\
\text { overall }\end{array}$ & $\begin{array}{c}\text { Sole } \\
\operatorname{del}(6 q)\end{array}$ & Normal & $\begin{array}{c}\text { Sole } \\
\operatorname{del}(13 q)\end{array}$ & $\begin{array}{l}\text { Sole tri- } \\
\text { somy } 12\end{array}$ & $\begin{array}{c}\text { Sole } \\
\operatorname{del}(17 p)\end{array}$ \\
\hline Risk & \multicolumn{5}{|c|}{ Intermediate } & \multicolumn{3}{|c|}{ Low } & $?$ \\
\hline Median TTFT (m.) & 2. & 1. & 3. & 4. & 5. & 7. & 6. & 8. & - \\
\hline $\begin{array}{l}\% \text { of p. with tr. in less than } 2 \\
\text { y. out of all p. in the subg. }\end{array}$ & 3. & 5. & 2. & 4. & 1. & 7. & 6. & 8. & - \\
\hline $\begin{array}{l}\% \text { of p. with CR out of all p. } \\
\text { with tr. in the subg. }\end{array}$ & 2. & 1. & 4. & 7. & 5. -6 . & 3. & 8. & $5 .-6$. & - \\
\hline $\begin{array}{l}\% \text { of p. died out of all p. in } \\
\text { the subg. }\end{array}$ & 1. & 4. & 2. & 6. & 8. & 5. & 7. & 3. & - \\
\hline Median Value & 2 & 2.5 & 2.5 & 5 & 5.3 & 6 & 6.5 & 6.8 & - \\
\hline
\end{tabular}

Abbreviations: abn., abnormality; CR, complete remission; kar., karyotype; m., months; p., patients; subg., subgroup; tr., treatment; TTFT, time to first treatment; y., years 
ages of deceased patients. Results for each of these characteristics were ranked from the most negative (1) to the most positive, and then median rank values were calculated for each of the cytogenetic subgroups. Based on primary abnormalities, the order of main categories from those with high risk to low risk was as follows (sorted according to median rank values): $1.8-\operatorname{Del}(17 p), 2.5-\operatorname{Del}(11 q), 4.3-\operatorname{Del}(6 q)$, 4.5 - Ambiguous, 4.8 - Trisomy 12, 6.8 - Other abnormality, 6.8 - Del(13q), 7 - Normal. According to types of abnormalities and karyotype complexity, the order of main categories from high risk to low risk was this: 2 - Sole del(11q), 2.5 - Sole other abnormality, 2.5 - Minimum three abnormalities, 5 - Two abnormalities, 5.3 - Sole del(6q), 6 - Normal, 6.5 - Sole del(13q), 6.8 - Sole trisomy 12; no case with Sole $\operatorname{del}(17 \mathrm{p})$ was revealed. The comparison is visualized in Table 4. Survival analyses with TTFT were performed and are disclosed in Figure 1.

Patients with two cytogenetic abnormalities - stratification based on primary abnormalities. According to primary cytogenetic abnormalities, patients with two abnormalities were divided into five subcategories: 1) 13q14 deletion ( $\mathrm{N}=13 ; 46 \%), 2)$ Trisomy $12(\mathrm{~N}=4 ; 14 \%), 3)$ Other primary abnormality $(\mathrm{N}=4 ; 14 \%), 4)$ Ambiguous primary abnormality ( $\mathrm{N}=3 ; 11 \%)$, and joint category 5) 11q22/ATM, 17p13/TP53, and 6q21/SEC63 deletions $(\mathrm{N}=4 ; 14 \%)$. No patient was indicated for CLL treatment in the subcategory 4) Ambiguous primary abnormality, which consisted of one case with $\operatorname{Del}(13 \mathrm{q})$ and trisomy 12, and two cases with $\operatorname{Del}(13 q)$ and $14 q 32$ rearrangement.

The following median TTFTs were calculated for the rest: 5 m. - Trisomy 12, 12 m. - $\operatorname{Del}(11 \mathrm{q}) / \operatorname{Del}(17 \mathrm{p}) / \operatorname{Del}(6 \mathrm{q}), 21$ m. - Del(13q), and $42 \mathrm{~m}$. - Other abnormality. Percentages of patients who started treatment for CLL in less than 2 years from diagnosis from all patients in the subgroup were: $100 \%$ - $\operatorname{Del}(11 q) / \operatorname{Del}(17 \mathrm{p}) / \operatorname{Del}(6 \mathrm{q}), 50 \%$ - Trisomy 12, 46\% $\operatorname{Del}(13 q)$, and $0 \%$ - Other abnormality. Percentages of patients who achieved CR after first line therapy, out of all patients with treatment in the subgroup, were: 50\% - $\operatorname{Del}(11 \mathrm{q}) / \operatorname{Del}(17 \mathrm{p}) /$ $\operatorname{Del}(6 q), 50 \%$ - Trisomy 12, 90\% - Del(13q), and 100\% Other abnormality. Percentages of patients who died during the follow-up of the study from all patients in the subgroup were: $50 \%-\operatorname{Del}(11 q) / \operatorname{Del}(17 p) / \operatorname{Del}(6 q), 25 \%$ - Trisomy 12, $0 \%-\operatorname{Del}(13 q)$, and $0 \%$ - Other abnormality. Results of the stratification are presented in Table S2 and an example of the cytogenetic analysis in a patient with two abnormalities (patient ID 135) is shown in Figure 2.

Patients with two cytogenetic abnormalities - stratification based on abnormality types. Patients with two abnormalities were sorted into six subcategories According to cytogenetic abnormality type: 1) 13q14 deletion and trisomy $12(\mathrm{~N}=4 ; 14 \%), 2)$ 13q14 deletion and 11q22/ATM deletion ( $\mathrm{N}=5 ; 18 \%), 3)$ Biallelic $13 \mathrm{q} 14$ deletion $(\mathrm{N}=6 ; 21 \%)$, 4) $13 q 14$ deletion and others $(\mathrm{N}=7 ; 25 \%), 5)$ Two abnormalities including 17p13/TP53 deletion ( $\mathrm{N}=1 ; 4 \%)$, and 6) Two abnormalities including $14 \mathrm{q} 32$ rearrangement $(\mathrm{N}=5 ; 18 \%)$.
The following median TTFTs were calculated for the six subcategories: $3 \mathrm{~m}$. - Two incl. 14q32, $9 \mathrm{~m}$. - Del(13q) and trisomy 12, 13 m. - Two incl. del(17p), 13 m. - Del(13q) and others, $18 \mathrm{~m}$. - Biallelic $\operatorname{del}(13 \mathrm{q})$, and $26 \mathrm{~m}$. - Del(13q) and del(11q). Percentages of patients who started treatment for CLL in less than 2 years from diagnosis from all patients in the subgroup were: $100 \%$ - Two incl. del(17p), $50 \%$ - Del(13q) and trisomy 12, 50\% - Biallelic del(13q), $43 \%-\operatorname{Del}(13 q)$ and others, $40 \%-\operatorname{Del}(13 q)$ and $\operatorname{del}(11 q)$, $20 \%$ - Two incl. 14q32. Percentages of patients who achieved CR after first line therapy from all patients with treatment in the subgroup were: $0 \%$ - Two incl. $\operatorname{del}(17 p), 50 \%-\operatorname{Del}(13 q)$ and trisomy $12,75 \%$ - Biallelic del(13q), 80\% - Del(13q) and del(11q), 100\% - Del(13q) and others, 100\% - Two incl. 14q32. Percentages of patients who died during the follow-up
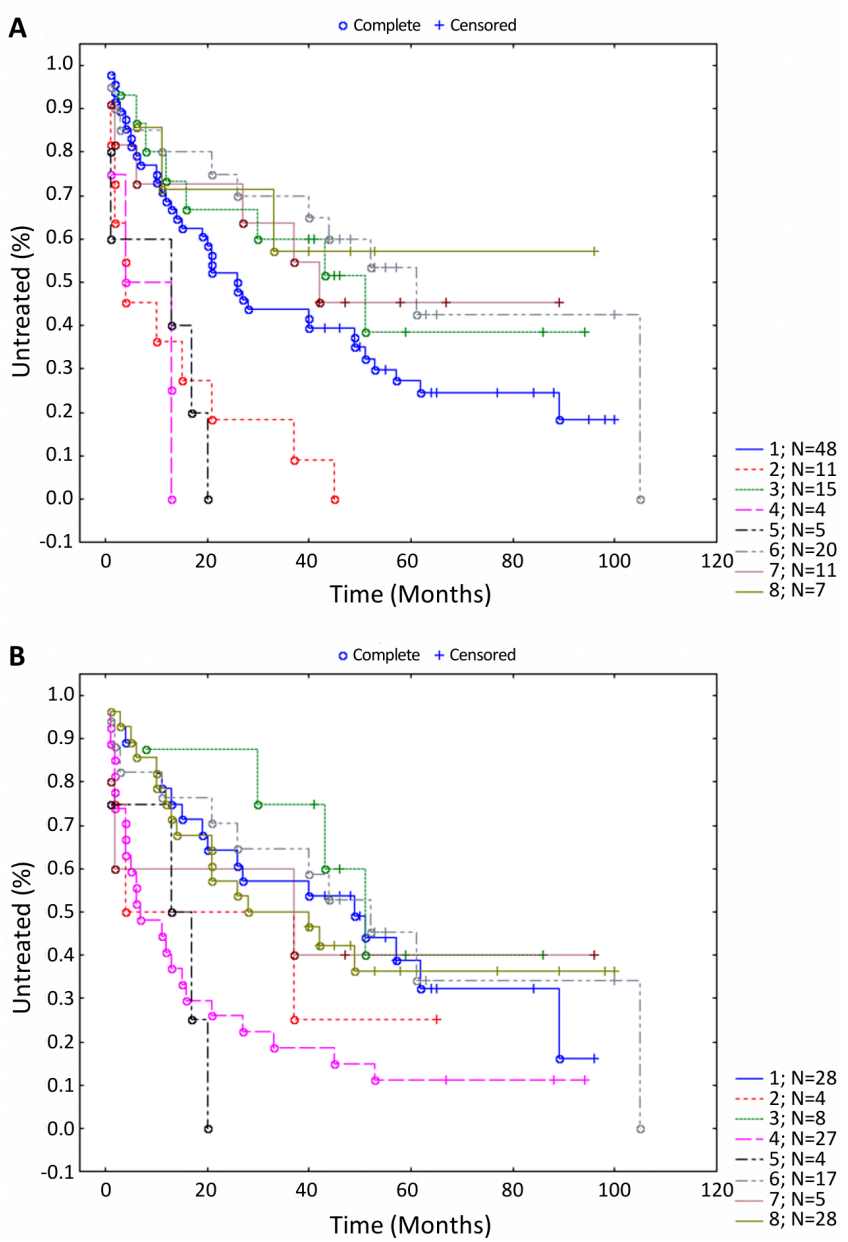

Figure 1. Whole cohort comparison. A) Whole cohort comparison of TTFT (Kaplan-Meier) for the main categories based on the determination of primary abnormalities $(1=\operatorname{del}(13 q) ; 2=\operatorname{del}(11 q) ; 3=$ trisomy 12 ; $4=\operatorname{del}(17 \mathrm{p}) ; 5=\operatorname{del}(6 q) ; 6=$ normal; $7=$ other abn; $8=$ ambiguous; Chisquare $=22.6, \mathrm{df}=7, \mathrm{p}=\mathbf{0 . 0 0 2}$ ), B) Whole cohort comparison of TTFT for the main categories based on the presence of certain cytogenetic abnormalities and karyotype complexity $(1=$ sole del13q; $2=$ sole del1 1q; $3=$ sole +12 ; $4=$ min three abn; $5=$ sole del6q; $6=$ normal; $7=$ sole others; $8=$ two abn; Chi-square $=19.2, \mathrm{df}=7, \mathrm{p}=0.008$ ). 


\section{A}
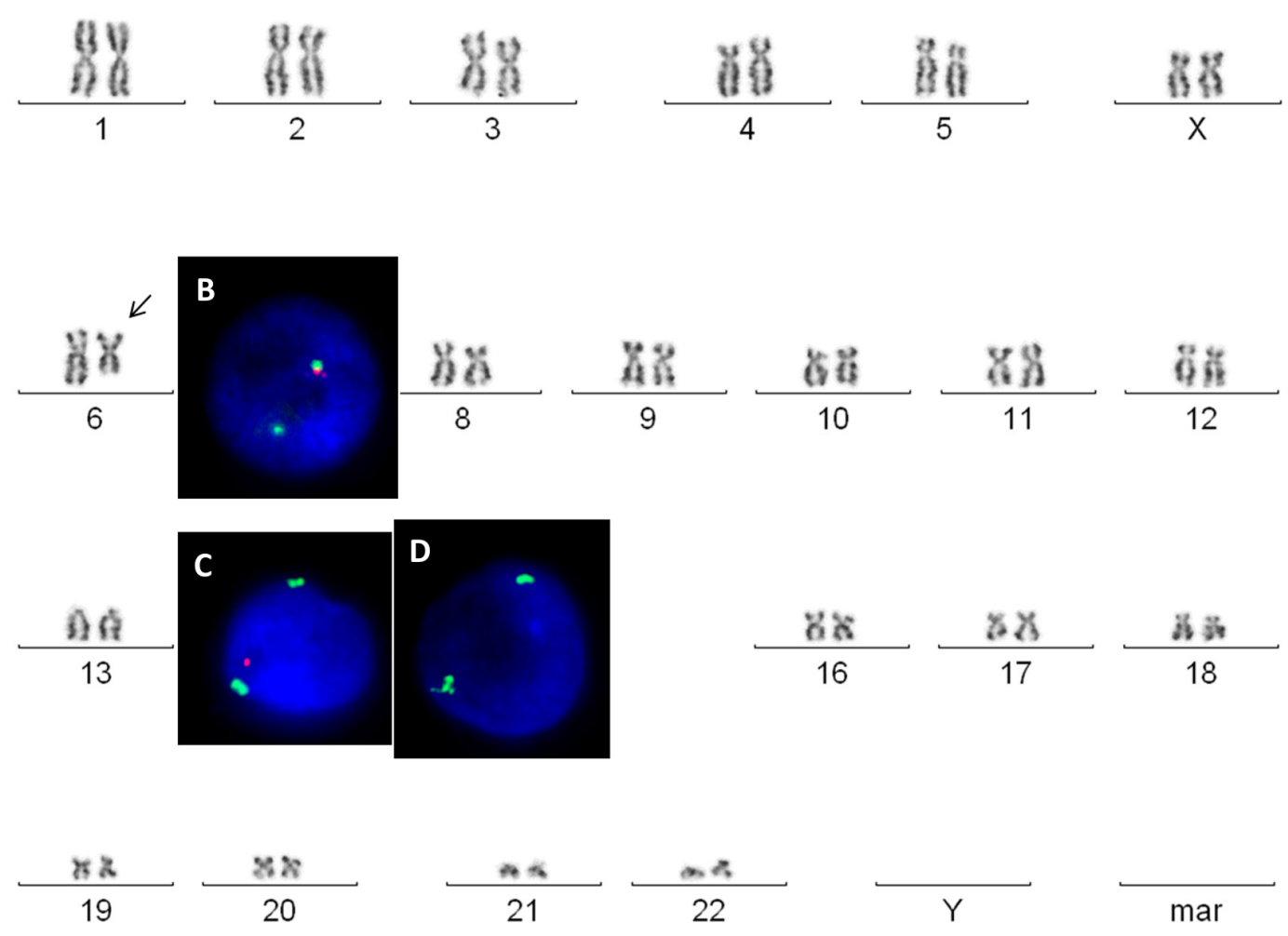

Figure 2. Cytogenetic analysis in a patient with three abnormalities (patient ID 109). A) Conventional karyotyping revealed deletion of 6q as a sole abnormality in 7/20 metaphases, B) FISH analysis confirmed deletion of 6q21 (SEC63) in 5/25 metaphases and 40\% interphase nuclei, C) FISH also revealed monoallelic deletion of $13 q$ (D13S319) in 27/30 metaphases and 71\% nuclei D) biallelic 13q deletion in $3 / 30$ metaphases and $10 \%$ nuclei. Deletion of $13 \mathrm{q}$ (cryptic for conventional karyotyping) can be reported as primary cytogenetic abnormality in this patient.

Table 5. Comparison of two stratification methods based on cytogenetics - patients with two abnormalities.

\begin{tabular}{|c|c|c|c|c|c|c|}
\hline I. Primary abn. & $\operatorname{Del}(11 q) / \operatorname{Del}(17 p) / \operatorname{Del}(6 q)$ & Trisomy 12 & $\operatorname{Del}(13 q)$ & Other abn & Ambiguous & \\
\hline Risk & \multicolumn{2}{|l|}{ High } & Intermed. & \multicolumn{2}{|c|}{ Low } & \\
\hline Median TTFT (m.) & 2. & 1. & 3. & 4. & 5. & \\
\hline $\begin{array}{l}\% \text { of p. with tr. in less than } 2 \mathrm{y} \text {. } \\
\text { out of all p. in the subg. }\end{array}$ & 1. & 2. & 3. & 4. -5 . & 4. -5. & \\
\hline $\begin{array}{l}\% \text { of } p . \text { with CR out of all p. with } \\
\text { tr. in the subg. }\end{array}$ & 1.- -2 . & 1.- -2 . & 3. & 4. -5 . & 4. -5 . & \\
\hline $\begin{array}{l}\% \text { of p. died out of all p. in the } \\
\text { subg. }\end{array}$ & 1 & 2 & 3. -5 . & 3. -5 . & 3.-5. & \\
\hline Median Value & 1.3 & 1.8 & 3 & 4.3 & 4.5 & \\
\hline $\begin{array}{l}\text { II. Type of abn. and kar. } \\
\text { complexity }\end{array}$ & Two incl del(17p) & $\begin{array}{l}\operatorname{Del}(13 q)+ \\
\text { trisomy } 12\end{array}$ & $\begin{array}{c}\operatorname{Del}(13 q)+ \\
\text { other abn }\end{array}$ & $\begin{array}{l}\text { Bialellic } \\
\text { del(13q) }\end{array}$ & $\begin{array}{c}\operatorname{Del}(13 q)+ \\
\operatorname{del}(11 q)\end{array}$ & $\begin{array}{c}\text { Two incl } 14 q 32 \\
\text { rear }\end{array}$ \\
\hline Risk & \multicolumn{2}{|l|}{ High } & \multicolumn{2}{|c|}{ Intermediate } & \multicolumn{2}{|c|}{ Low } \\
\hline Median TTFT (m.) & 3. -4 . & 2. & 3.-4. & 5. & 6. & 1. \\
\hline $\begin{array}{l}\% \text { of p. with tr. in less than } 2 \mathrm{y} \text {. } \\
\text { out of all p. in the subg. }\end{array}$ & 1. & 2.-3. & 4. & 2.-3. & 5. & 6. \\
\hline $\begin{array}{l}\% \text { of p. with CR out of all p. with } \\
\text { tr. in the subg. }\end{array}$ & 1. & 2. & 5. -6 . & 3. & 4. & 5. -6. \\
\hline $\begin{array}{l}\% \text { of p. died out of all p. in the } \\
\text { subg. }\end{array}$ & 1. & 2. & 3. & 4. -6. & 4. -6 . & 4.-6. \\
\hline Median Value & 1 & 2 & 3.8 & 4 & 5 & 5.3 \\
\hline
\end{tabular}

Abbreviations: abn., abnormality; CR, complete remission; intermed., intermediate; kar., karyotype; m., months; p., patients; subg., subgroup; tr., treatment; TTFT, time to first treatment; y., years 
of the study from all patients in the subgroup were: $100 \%$ - Two incl. del(17p), 25\% - Del(13q) and trisomy 12, 14\% $\operatorname{Del}(13 q)$ and others, $0 \%$ - Biallelic $\operatorname{del}(13 q), 0 \%-\operatorname{Del}(13 q)$ and del(11q), $0 \%$ - Two incl. 14q32. Details of the stratification are disclosed in Table S3.

Patients with two cytogenetic abnormalities - comparison of two stratifications. Comparison of the two stratification methods in patients with two cytogenetic abnormalities was performed in the same manner as for the whole study cohort. Based on primary abnormalities, the order of subcategories from those with high risk to low risk was as follows (sorted according to median rank values): 1.3 - Del(11q)/ $\operatorname{Del}(17 \mathrm{p}) / \operatorname{Del}(6 \mathrm{q}), 1.8$ - Trisomy 12, 3 - $\operatorname{Del}(13 \mathrm{q}), 4.3$ Other abnormality, and 4.5 - Ambiguous. According to types of abnormalities, the order of subcategories from high risk to low risk was this: $1-$ Two incl. $\operatorname{del}(17 p), 2-\operatorname{Del}(13 q)$ and trisomy 12, 3.8 - Del(13q) and others, $4-$ Biallelic del(13q), 5 - Del(13q) and del(11q), 5.3 - Two incl. 14q32. The comparison is presented in Table 5. Similarly, a comparison of TTFTs via the Kaplan-Meier method for patients with two abnormalities is shown in Figure 3.

Patients with complex karyotypes - stratification based on primary abnormalities. According to primary cytogenetic abnormalities, patients with complex karyotype (CK) were divided into six subcategories: 1) 13q14 deletion ( $N=9$; $33 \%)$, 2) Trisomy $12(\mathrm{~N}=3 ; 11 \%), 3) 11 \mathrm{q} 22 / \mathrm{ATM}$ deletion $(\mathrm{N}=6 ; 22 \%), 4) 17 \mathrm{p} 13 / \mathrm{TP} 53$ deletion $(\mathrm{N}=3 ; 11 \%), 5)$ Other primary abnormality $(\mathrm{N}=3 ; 11 \%)$, and 6) Ambiguous primary abnormality $(\mathrm{N}=3 ; 11 \%)$.

The following median TTFTs were calculated for the subcategories: $3 \mathrm{~m}$. - $\operatorname{Del}(11 \mathrm{q}), 4 \mathrm{~m}$. - $\operatorname{Del}(17 \mathrm{p}), 5 \mathrm{~m}$. $\operatorname{Del}(13 \mathrm{q}), 11 \mathrm{~m}$. - Ambigous, $14 \mathrm{~m}$. - Trisomy 12, and $17 \mathrm{~m}$. - Others. Percentages of patients who started treatment for CLL in less than 2 years from diagnosis from all patients in the subgroup were: $100 \%-\operatorname{Del}(17 \mathrm{p}), 83 \%-\operatorname{Del}(11 \mathrm{q}), 78 \%$ - Del(13q), 67\% - Ambigous, 67\% - Trisomy 12, and 33\% Others. Percentages of patients who achieved CR after first line therapy from all patients with treatment in the subgroup were: $0 \%$ - Others, $33 \%$ - Del(17p), 50\% - Trisomy 12, 75\% $\operatorname{Del}(13 q), 100 \%$ - Del(11q), and 100\% - Ambigous. Percentages of patients who died during the follow-up of the study from all patients in the subgroup were: $100 \%-\operatorname{Del}(17 \mathrm{p})$, $67 \%$ - Ambigous, 33\% - Del(11q), 11\% - Del(13q), 0\% Trisomy 12 , and $0 \%$ - Others. The results of the stratification are collected in Table S4.

Patients with complex karyotypes - stratification based on abnormality types or complexity. Two variants of stratification were conducted in patients with $\mathrm{CK}$ according to abnormality types (CK variant 1 ) or karyotype complexity (CK variant 2). CK variant 1 stratification split the $\mathrm{CK}$ category into three subcategories: 1$) \mathrm{CK}$ incl. $\operatorname{del}(17 \mathrm{p})(\mathrm{N}=6$; $22 \%), 2) \mathrm{CK}$ incl. del(11q) without $\operatorname{del}(17 \mathrm{p})(\mathrm{N}=13 ; 48 \%)$, and 3) CK without $\operatorname{del}(11 \mathrm{q})$ or $\operatorname{del}(17 \mathrm{p})(\mathrm{N}=8 ; 30 \%)$. CK variant 2 stratification split the $\mathrm{CK}$ category also into three subcategories: 1) Three abnormalities (abn.) overall ( $\mathrm{N}=13$;
48\%), 2) Four abn. overall ( $\mathrm{N}=4 ; 15 \%)$, and 3) Minimum (min.) five abn. overall $(\mathrm{N}=10 ; 37 \%)$.

The following median TTFTs were calculated for the CK variant 1 subcategories: $4 \mathrm{~m}$. - CK incl. del(17p), 5 m. - CK incl. del(11q) without del(17p), 10 m. - CK without del(11q) or $\operatorname{del}(17 \mathrm{p})$, and the CK variant 2 subcategories: $3 \mathrm{~m}$. - Four abn., 6 m. - Min. five abn., $11 \mathrm{~m}$. - Three abn. Percentages of patients who started treatment for CLL in less than 2 years from diagnosis from all patients in the subgroup were for the CK variant 1: $83 \%$ - CK incl. del(17p), 77\% - CK incl. $\operatorname{del}(11 q)$ without $\operatorname{del}(17 p), 63 \%$ - CK without $\operatorname{del}(11 q)$ or del(17p), and the CK variant 2: $80 \%$ - Min. five abn., 75\% - Four abn., 69\% - Three abn. Percentages of patients who achieved CR after first line therapy from all patients with treatment in the subgroup were for the CK variant 1:20\%CK incl. del(17p), 83\% - CK without del(11q) or $\operatorname{del}(17 \mathrm{p})$, $85 \%$ - CK incl. del(11q) without del(17p), and the CK variant 2: $44 \%$ - Min. five abn., 75\% - Four abn., 91\% - Three abn. Percentages of patients who died during the follow-up of the study from all patients in the subgrou, were for the CK variant 1: $67 \%$ - CK incl. del(17p), $23 \%$ - CK incl. del(11q) without $\operatorname{del}(17 p), 13 \%$ - CK without $\operatorname{del}(11 q)$ or $\operatorname{del}(17 p)$, and the CK variant 2: 50\% - Min. five abn., 25\% - Four abn., $15 \%$ - Three abn. Results of both variants of stratification are shown in Table S5.

Patients with complex karyotypes - comparison of two stratifications. A similar comparison of the two stratification methods for patients with complex karyotypes was performed. Based on primary abnormalities, the order of subcategories from those with high risk to low risk was as follows (sorted according to median rank values): 1.5 $\operatorname{Del}(17 p), 2.5$ - $\operatorname{Del}(11 q), 3.5$ - $\operatorname{Del}(13 q), 4.3$ - Ambigous, 4.8 - Trisomy 12, and 5.8 - Others. For the evaluation of the stratification according to types of abnormalities or karyotype complexity (CK variant 1 and 2 ) the subcategories from both variants were ranked altogether. The lowest median rank values (meaning the highest risk) were calculated for the subcategories CK incl. del(17p) and Min. five abn. overall (values 1 and 2, respectively). Values 3 and 3.5 were assigned to the subcategories Four abn. overall and CK incl. del(11q) without del(17p). The highest values (meaning the lowest risk from the CK category) were assigned to the subcategories CK without $\operatorname{del}(11 \mathrm{q})$ or $\operatorname{del}(17 \mathrm{p})$ and Three abn. overall (value 5.5 for both). The comparison is compiled in Table 6 and the comparison of TTFTs via the Kaplan-Meier method for patients with $\mathrm{CK}$ is given in Figure 4.

\section{Discussion}

Cytogenetic analysis has become standard procedure in the initial phase of diagnostics in many types of hematological malignancies. It is standard practice in cytogenetic reports to give prognostic information based on the presence of certain abnormalities and karyotype complexity. This approach in chronic lymphocytic leukemia (CLL) is based 

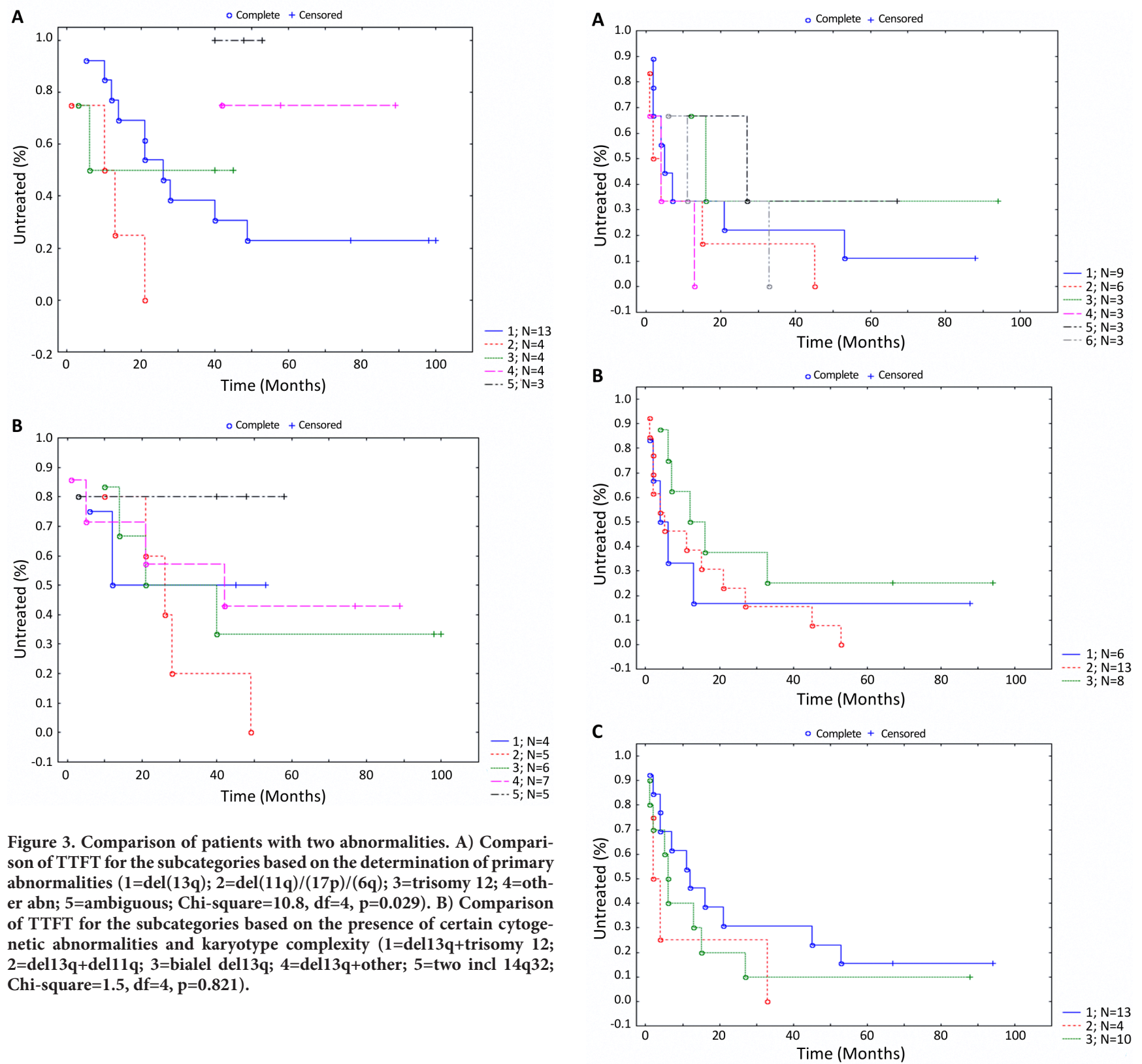

Figure 3. Comparison of patients with two abnormalities. A) Comparison of TTFT for the subcategories based on the determination of primary abnormalities $(1=\operatorname{del}(13 q) ; 2=\operatorname{del}(11 q) /(17 p) /(6 q) ; 3=$ trisomy $12 ; 4=$ other abn; $5=$ ambiguous; Chi-square $=10.8, \mathrm{df}=4, \mathrm{p}=0.029$ ). B) Comparison of TTFT for the subcategories based on the presence of certain cytogenetic abnormalities and karyotype complexity $(1=$ del13q+trisomy 12 ; 2=del13q+del11q; 3=bialel del13q; 4=del13q+other; $5=$ two incl 14q32; Chi-square $=1.5, \mathrm{df}=4, \mathrm{p}=0.821$ ).

on stratification reported by Dohner et al. [23]. Patients with pathological clones containing more than one cytogenetic abnormality are generally in the higher risk category, although their performance is very heterogeneous. Where more cytogenetic abnormalities are revealed, primary cytogenetic abnormalities are sometimes not so obvious and are not explicitly reported in the text of cytogenetic reports.

Would information explicitly determining the primary cytogenetic abnormality, when standardly reported in the text of cytogenetic reports, bring some added value in hematologic patient risk stratification? Answering this question was one of the main objectives of the current retrospective study. Two different methods for CLL patient stratification based on the results of cytogenetic analyses - oriented to primary

Figure 4. Comparison of patients with complex karyotypes. A) Comparison of TTFT for the subcategories based on the determination of primary abnormalities $(1=$ del13q; $2=$ del11q; $3=$ trisomy $12 ; 4=$ del17p; $5=$ other abn; $6=$ ambiguous; Chi-square $=6.6, \mathrm{df}=5, \mathrm{p}=0.256$ ). $\mathrm{B}$ ) Comparison of TTFT for the subcategories based on the presence of certain cytogenetic abnormalities $(1=$ incl del17p; $2=$ incl del11q, not $17 \mathrm{p} ; 3=$ not del11q or $17 \mathrm{p}$; Chi-square $=3, \mathrm{df}=2, \mathrm{p}=0.222$ ) or $\mathrm{C}$ ) karyotype complexity ( $1=$ three abn; $2=$ four abn; $3=\min$ five abn; Chi-square $=1.9, \mathrm{df}=2, \mathrm{p}=0.387$ )

abnormalities or to abnormality types and complexity - were compared. 121 patients without the need to start the treatment for CLL immediately after diagnosis and with successful initial cytogenetic analysis (the study cohort) were selected from 146 consecutive CLL cases diagnosed from 2009 to 
Table 6. Comparison of two methods for stratification based on cytogenetics - complex karyotypes.

\begin{tabular}{|c|c|c|c|c|c|c|}
\hline I. Primary abn. & $\operatorname{Del}(17 p)$ & $\operatorname{Del}(11 q)$ & $\operatorname{Del}(13 q)$ & Ambiguous & Trisomy 12 & Other abn \\
\hline Risk & \multicolumn{3}{|c|}{ High } & \multicolumn{3}{|c|}{ Intermediate } \\
\hline Median TTFT (m.) & 2. & 1. & 3. & 4. & 5. & 6. \\
\hline $\begin{array}{l}\% \text { of p. with tr. in less than } 2 \text { y. out of all } \\
\text { p. in the subg. }\end{array}$ & 1. & 2. & 3. & $4 .-5$. & 4.-5. & 6. \\
\hline $\begin{array}{l}\% \text { of } p \text {. with CR out of all p. with tr. in } \\
\text { the subg. }\end{array}$ & 2. & 5.-6. & 4. & 5.-6. & 3. & 1. \\
\hline$\%$ of p. died out of all p. in the subg. & 1. & 3. & 4. & 2. & 5.-6. & 5.-6. \\
\hline Median Value & 1.5 & 2.5 & 3.5 & 4.3 & 4.8 & 5.8 \\
\hline II. Type of abn. and kar. complexity & $\begin{array}{l}\text { Compl kar incl } \\
\text { del }(17 p)\end{array}$ & $\begin{array}{c}\text { Compl kar incl } \\
\operatorname{del}(11 q) \text { without } \\
\text { del }(17 p)\end{array}$ & $\begin{array}{c}\text { Compl kar with- } \\
\text { out del(11q) or } \\
\operatorname{del}(17 p)\end{array}$ & $\begin{array}{l}\text { Min five abn } \\
\text { overall }\end{array}$ & $\begin{array}{c}\text { Four abn } \\
\text { overall }\end{array}$ & $\begin{array}{c}\text { Three abn } \\
\text { overall }\end{array}$ \\
\hline Risk & High & & Int. & High & & Int. \\
\hline Median TTFT (m.) & 2. & 3. & 5. & 4. & 1. & 6. \\
\hline $\begin{array}{l}\% \text { of p. with tr. in less than } 2 \text { y. out of all } \\
\text { p. in the subg. }\end{array}$ & 1. & 3. & 6. & 2. & 4. & 5. \\
\hline $\begin{array}{l}\% \text { of } p \text {. with CR out of all p. with tr. in } \\
\text { the subg. }\end{array}$ & 1. & 5. & 4. & 2. & 3. & 6. \\
\hline$\%$ of p. died out of all p. in the subg. & 1. & 4. & 6. & 2. & 3. & 5. \\
\hline Median Value & 1 & 3.5 & 5.5 & 2 & 3 & 5.5 \\
\hline
\end{tabular}

Abbreviations: abn., abnormality; compl, complex; CR, complete remission; int., intermediate; kar., karyotype; m., months; p., patients; subg., subgroup; tr., treatment; TTFT, time to first treatment; y., years

2012. Results from conventional karyotyping after stimulation of CLL cells and FISH analysis were then combined.

(1) A three step procedure was proposed for the precise determination of primary cytogenetic abnormalities. These rules were then applied to divide the study cohort into eight main categories. As a final result of this stratification approach, the main categories Deletion of $17 \mathrm{p}$ and Deletion of $11 \mathrm{q}$ were considered as high risk categories, Deletion of 6q, Ambiguous abnormality and Trisomy 12 as intermediate, and Other abnormality, Deletion of $13 \mathrm{q}$ and Normal karyotype as low risk. In parallel, all patients were divided into nine main categories according to the presence of certain cytogenetic abnormalities and karyotype complexity. This approach ended with the result of Sole deletion of 11q, Sole other abnormality and Minimum three abnormalities as high risk categories, Two abnormalities and Sole deletion of $6 \mathrm{q}$ as intermediate, and Normal karyotype, Sole deletion of $13 \mathrm{q}$ and Sole trisomy 12 as low risk and no patient with Sole deletion of $17 \mathrm{p}$ was found. The results of the second approach are consistent with results previously published in larger studies [23-26].

Interestingly, stratification based purely on the determination of primary cytogenetic abnormalities, regardless of karyotype complexity, was also effective in CLL patient risk stratification; with results similar to the more established method. Deletions of 17p/TP53 and 11q/ATM were connected with highest risk in our patients, as also proven in many previous studies. As expected, the main categories Trisomy 12 and Deletion of $6 \mathrm{q}$ showed worse results in the stratification of primary abnormalities than their counterpart categories Sole trisomy 12 and Sole deletion of $6 \mathrm{q}$ in the second method stratification. Notably, the abnormality deletion of $13 \mathrm{q}$ showed superior results and lowest risk even in the category based on primary abnormality determination, where patients with more abnormalities were also included.

(2) We then focused on patients who had two cytogenetic abnormalities in their pathological CLL clones. Although these patients comprise quite a large subgroup, current information is limited. Our results indicated that this main category accounted for approximately $20 \%$ of CLL patients and was generally connected with intermediate risk. Furthermore, it was demonstrated that the risk stratification based on the determination of primary abnormalities was also effective in this specific sub-group of patients. Unexpectedly, the sub-categories Trisomy 12 (primary abnormality stratification) and Deletion of 13q plus trisomy 12 (abnormality type stratification) had higher risk characteristics in the Two abnormalities category than the sub-categories Deletion of $13 \mathrm{q}$ plus deletion of $11 \mathrm{q}$ and Two abnormalities including $14 \mathrm{q} 32$ rearrangement. The sub-category Two abnormalities including $14 \mathrm{q} 32$ rearrangement consisted of two patients with concomitant trisomy 12 and three with deletion of $13 \mathrm{q}$, and these had the lowest TTFT. This result is consistent with the observation of Gerrie et al. [20], who reported that patients with deletion of $13 \mathrm{q}$ and an $I G H$ translocation had significantly worse treatment free survival than those without IGH translocation. However, when other characteristics were considered, the sub-category Two abnormalities including $14 \mathrm{q} 32$ rearrangement had the lowest risk of all the patients with two abnormalities in the current study.

Puiggros et al. [14] and others reported that loss of the remaining $13 \mathrm{q}$ allele (bi-allelic deletion of $13 \mathrm{q}$ ) is not 
enough to predict worse prognosis in CLL. In our cohort, the sub-category Bi-allelic deletion of $13 \mathrm{q}$ had a slightly shorter median TTFT (18 vs. 20 months) compared to the main category Sole deletion of 13q (monoallelic deletion) There was a higher percentage of patients who started the treatment for CLL in less than 2 years from diagnosis (50\% vs. $36 \%$ ), and a lower percentage of patients who achieved CR after first line therapy ( $75 \%$ vs. $89 \%)$. However, the percentage of patients who died was lower $(0 \%$ vs. $4 \%)$ and bi-allelic deletion had intermediate performance compared to the other sub-categories. These agree with previously published results.

The results of the current study could not confirm some results reported by Van Dyke et al. [27]. These authors investigated the effect of 13q deletion on the CLL clinical course with a second FISH abnormality and reported that no significant difference was observed in OS for patients with 11q deletion or trisomy 12, based on whether or not there was a concomitant 13q deletion. Surprisingly, their study recorded that OS was significantly longer for $17 \mathrm{p}$ deletion patients with a concomitant $13 \mathrm{q}$ deletion than without $13 \mathrm{q}$ deletion. It would be interesting to determine the primary abnormalities in those patients, but this was impossible from the information provided in the article.

(3) The patients with complex karyotypes (CK), known to be high-risk patients, were then studied in detail and the risk stratification according to primary abnormalities was also effective for this category. In the stratification where certain types of abnormalities or karyotype complexity were considered, CK including deletion of $11 \mathrm{q}$ without deletion of $17 \mathrm{p}$ showed better results than CK including deletion of $17 \mathrm{p}$, but worse results than CK without either of these two abnormalities; as expected. Similarly, CK consisting of four abnormalities had better characteristics than CK with a minimum of five abnormalities, but worse than CK with three abnormalities. Baliakas et al. [28] support our findings that patients with five or more cytogenetic abnormalities follow particularly aggressive clinical courses even compared to CK cases with 3-4 abnormalities

In conclusion, to the best of our knowledge this is the first study specifically focusing on the value of information on precise determination of primary cytogenetic abnormalities in chronic lymphocytic leukemia patient pathological clones. Moreover, detailed cytogenetic characterization of the specific patient sub-set with two abnormalities and complex karyotypes has provided much needed information on these numerous CLL subgroups. Finally, although this study is limited by the single center approach and validation in larger cohorts would be advantageous, our results indicate that precise determination of the primary cytogenetic abnormality in chronic lymphocytic leukemia has provided value to clinical risk stratification.

Supplementary information is available in the online version of the paper.
Acknowledgements: This work was supported by grant No. CZ.02.1.01/0.0/0.0/16_013/0001634 National Center for Medical Genomic - 'modernization of infrastructure and research of genetic variation in the population' funded by OP RDE; and partly by the National Sustainability Program I (NPU I) provided by the Ministry of Education Youth and Sports of the Czech Republic (project no. LO1503).

\section{References}

[1] SWERDLOW SH, CAMPO E, HARRIS NL, JAFFE ES, PILERI SA et al. (Eds.). WHO Classification Of Tumours Of Haematopoietic and Lymphoid Tissues. International Agency for Research on Cancer (IARC), Lyon 2008, p 585. ISBN 978-9283244943

[2] VAN BOCKSTAELE F, VERHASSELT B, PHILIPPE J. Prognostic markers in chronic lymphocytic leukemia: A comprehensive review. Blood Rev 2009; 23: 25-47. https:// doi.org/10.1016/j.blre.2008.05.003

[3] RINALDI A, MIAN M, KWEE I, ROSSI D, DEAMBROGI $C$ et al. Genome-wide DNA profiling better defines the prognosis of chronic lymphocytic leukaemia. Br J Haematol 2011; 154: 590-599. https://doi.org/10.1111/j.13652141.2011.08789.x

[4] SUTTON L, LJUNGSTROM V, MANSOURI L, YOUNG E, CORTESE D et al. Targeted next-generation sequencing in chronic lymphocytic leukemia: a high-throughput yet tailored approach will facilitate implementation in a clinical setting. Haematologica 2014; 100: 370-376. https://doi. org/10.3324/haematol.2014.109777

[5] ZENZ T, FROHLING S, MERTENS D, DOHNER H, STILGENBAUER S. Moving from prognostic to predictive factors in chronic lymphocytic leukaemia (CLL). Best Pract Res Clin Haematol 2010; 23: 71-84. https://doi.org/10.1016/j. beha.2009.12.003

[6] PEKARSKY Y, CROCE C. Role of miR-15/16 in CLL. Cell Death Differ 2015; 22: 6-11. https://doi.org/10.1038/ cdd.2014.87

[7] PUIGGROS A, BLANCO G, ESPINET B. Genetic Abnormalities in Chronic Lymphocytic Leukemia: Where We Are and Where We Go. Biomed Res Int 2014; 2014: 1-13. https:// doi.org/10.1155/2014/435983

[8] DICKER F, SCHNITTGER S, HAFERLACH T, KERN W, SCHOCH C. Immunostimulatory oligonucleotideinduced metaphase cytogenetics detect chromosomal aberrations in $80 \%$ of CLL patients: a study of 132 CLL cases with correlation to FISH, IgVH status, and CD38 expression. Blood 2006; 108: 3152-3160. https://doi.org/10.1182/ blood-2006-02-005322

[9] HAFERLACH C, DICKER F, SCHNITTGER S, KERN W, HAFERLACH T. Comprehensive genetic characterization of CLL: a study on 506 cases analysed with chromosome banding analysis, interphase FISH, IgVH status and immunophenotyping. Leukemia 2007; 21: 2442-2451. https://doi. org/10.1038/sj.leu.2404935 
[10] MAYR C, SPEICHER MR, KOFLER DM, BUHMANN $\mathrm{R}$, STREHL J et al. Chromosomal translocations are associated with poor prognosis in chronic lymphocytic leukemia. Blood 2006; 107: 742-751. https://doi.org/10.1182/ blood-2005-05-2093

[11] VAN DEN NESTE E, ROBIN V, FRANCART J, HAGEMEIJER A, STUL M et al. Chromosomal translocations independently predict treatment failure, treatment-free survival and overall survival in B-cell chronic lymphocytic leukemia patients treated with cladribine. Leukemia 2007; 21: 17151722. https://doi.org/10.1038/sj.leu.2404764

[12] RIGOLIN G, CIBIEN F, MARTINELLI S, FORMIGARO L, RIZZOTTO L et al. Chromosome aberrations detected by conventional karyotyping using novel mitogens in chronic lymphocytic leukemia with "normal" FISH: correlations with clinicobiologic parameters. Blood 2012; 119: 23102313. https://doi.org/10.1182/blood-2011-11-395269

[13] HERNANDEZ J, RODRIGUEZ A, GONZALEZ M, BENITO R, FONTANILLO C et al. A high number of losses in $13 q 14$ chromosome band is associated with a worse outcome and biological differences in patients with B-cell chronic lymphoid leukemia. Haematologica 2009; 94: 364-371. https://doi.org/10.3324/haematol.13862

[14] PUIGGROS A, DELGADO J, RODRIGUEZ-VICENTE A, COLLADO R, AVENTIN A et al. Biallelic losses of 13q do not confer a poorer outcome in chronic lymphocytic leukaemia: analysis of 627 patients with isolated 13q deletion. Br J Haematol 2013; 163: 47-54. https://doi.org/10.1111/ bjh.12479

[15] RODRIGUEZ A, HERNANDEZ J, BENITO R, GUTIERREZ NC, GARCIA JL et al. Molecular Characterization of Chronic Lymphocytic Leukemia Patients with a High Number of Losses in 13q14. PLoS One 2012; 7: e48485. https:// doi.org/10.1371/journal.pone.0048485

[16] HUANG S, GILLAN T, GERRIE A, HRYNCHAK M, KARSAN A et al. Influence of clone and deletion size on outcome in chronic lymphocytic leukemia patients with an isolated deletion $13 \mathrm{q}$ in a population-based analysis in British Columbia, Canada. Genes Chromosomes Cancer 2016; 55: 16-24. https://doi.org/10.1002/gcc.22294

[17] MARASCA R, MAFFEI R, MARTINELLI S, FIORCARI S, BULGARELLI J et al. Clinical heterogeneity of de novo 11q deletion chronic lymphocytic leukaemia: prognostic relevance of extent of $11 \mathrm{q}$ deleted nuclei inside leukemic clone. Hematol Oncol 2013; 31: 88-95. https://doi.org/10.1002/ hon. 2028

[18] HERNANDEZ J, HERNANDEZ-SANCHEZ M, RODRIGUEZ-VICENTE A, GROSSMANN V, COLLADO R et al. A Low Frequency of Losses in 11q Chromosome Is Associated with Better Outcome and Lower Rate of Genomic Mutations in Patients with Chronic Lymphocytic Leukemia. PLoS One 2015; 10: e0143073. https://doi.org/10.1371/journal.pone. 0143073
[19] LU G, KONG Y, YUE C. Genetic and immunophenotypic profile of IGH@ rearrangement detected by fluorescence in situ hybridization in 149 cases of B-cell chronic lymphocytic leukemia. Cancer Genetics Cytogenetics 2010; 196: 56-63. https://doi.org/10.1016/j.cancergencyto.2009.08.021

[20] GERRIE A, BRUYERE H, CHAN M, DALAL CB, RAMADAN KM et al. Immunoglobulin heavy chain (IGH@) translocations negatively impact treatment-free survival for chronic lymphocytic leukemia patients who have an isolated deletion 13q abnormality. Cancer Genet 2012; 205: 523-527. https://doi.org/10.1016/j.cancergen.2012.05.011

[21] HALLEK M, CHESON BD, CATOVSKY D, CALIGARISCAPPIO F, DIGHIERO G et al. Guidelines for the diagnosis and treatment of chronic lymphocytic leukemia: a report from the International Workshop on Chronic Lymphocytic Leukemia updating the National Cancer Institute-Working Group 1996 guidelines. Blood 2008; 111: 5446-5456. https:// doi.org/10.1182/blood-2007-06-093906

[22] SHAFFER LG, SLOVAK ML, CAMPBELL LJ (Eds.). ISCN 2009. An international system for human cytogenetic nomenclature (2009), 1st Edition. Karger, Basel 2009, p 138. ISBN 9783805589857

[23] DOHNER H, STILGENBAUER S, BENNER A, LEUPOLT E, KROBER A et al. Genomic Aberrations and Survival in Chronic Lymphocytic Leukemia. N Engl J Med 2000; 343: 1910-1916. https://doi.org/10.1056/nejm200012283432602

[24] CUNEO A, RIGOLIN G, BIGONI R, DE ANGELI C, VERONESE A et al. Chronic lymphocytic leukemia with 6qshows distinct hematological features and intermediate prognosis. Leukemia 2004; 18: 476-483. https://doi.org/10.1038/ sj.leu. 2403242

[25] HALLEK M. Chronic lymphocytic leukemia: 2015 Update on diagnosis, risk stratification, and treatment. Am J Hematol 2015; 90: 446-460. https://doi.org/10.1002/ajh.23979

[26] VAN DYKE D, WERNER L, RASSENTI L, NEUBERG D, GHIA E et al. The Dohner fluorescence in situ hybridization prognostic classification of chronic lymphocytic leukaemia (CLL): the CLL Research Consortium experience. Br J Haematol 2016; 173: 105-113. https://doi.org/10.1111/bjh.13933

[27] VAN DYKE D, SHANAFELT T, CALL T, ZENT CS, SMOLEY SA et al. A comprehensive evaluation of the prognostic significance of $13 \mathrm{q}$ deletions in patients with B-chronic lymphocytic leukaemia. Br J Haematol 2010; 148: 544-550. https://doi.org/10.1111/j.1365-2141.2009.07982.x

[28] BALIAKAS P, ISKAS M, GARDINER A, DAVIS Z, PLEVOVA $\mathrm{K}$ et al. Chromosomal translocations and karyotype complexity in chronic lymphocytic leukemia: A systematic reappraisal of classic cytogenetic data. Am J Hematol 2014; 89: 249-255. https://doi.org/10.1002/ajh.23618 


\section{Precise determination of primary cytogenetic abnormalities provides added value for stratification of chronic lymphocytic leukemia patients}

P. DVORAK ${ }^{1,2, *}$, D. LYSAK ${ }^{3,4}$, P. VOHRADSKA ${ }^{2}$, I. SUBRT ${ }^{2}$

Supplemental Material

Table S1. Summary of all laboratory and clinical data for the study cohort of 121 CLL patients (see online MS Excel version).

Table S2. Characteristics of cytogenetic subgroups based on the determination of primary abnormalities - patients with two abnormalities.

\begin{tabular}{|c|c|c|c|c|c|}
\hline Patients in subgroups & Trisomy 12 & $\begin{array}{c}\operatorname{Del}(11 q) / \operatorname{Del}(17 p) \\
/ \operatorname{Del}(6 q)\end{array}$ & $\operatorname{Del}(13 q)$ & Other abn & Ambiguous \\
\hline $\mathrm{N}$ & 4 & 4 & 13 & 4 & 3 \\
\hline$\%$ of all & 14 & 14 & 46 & 14 & 11 \\
\hline Males (N) & 3 & 4 & 8 & 3 & 3 \\
\hline Females $(\mathrm{N})$ & 1 & 0 & 5 & 1 & 0 \\
\hline Median age at dg. (y.) & 59 & 69 & 62 & 56 & 62 \\
\hline Treatment for other malignancy $(\mathrm{N})$ & 0 & 0 & 0 & 0 & 0 \\
\hline Rai 0 status (N) & 1 & 0 & 7 & 3 & 0 \\
\hline Rai 1 & 3 & 3 & 4 & 1 & 3 \\
\hline Rai 2 & 0 & 1 & 2 & 0 & 0 \\
\hline Median follow-up (m.) & 44 & 60 & 74 & 71 & 48 \\
\hline Treatment for CLL $(\mathrm{N})$ & 2 & 4 & 10 & 1 & 0 \\
\hline$\%$ of p. with treatment out of all p. in the subg. & 50 & 100 & 77 & 25 & 0 \\
\hline Median TTFT (m.) & 5 & 12 & 21 & 42 & - \\
\hline Treatment started in less than $2 \mathrm{y}$. after dg. $(\mathrm{N})$ & 2 & 4 & 6 & 0 & 0 \\
\hline$\%$ of p. with tr. in less than $2 \mathrm{y}$. out of all p. in the subg. & 50 & 100 & 46 & 0 & 0 \\
\hline $\mathrm{CR}$ after 1 . line therapy $(\mathrm{N})$ & 1 & 2 & 9 & 1 & 0 \\
\hline$\%$ of p. with CR out of all p. with tr. in the subg. & 50 & 50 & 90 & 100 & - \\
\hline $\mathrm{PR}$ after 1 . line therapy $(\mathrm{N})$ & 1 & 2 & 1 & 0 & 0 \\
\hline$\%$ of p. with PR out of all p. with tr. in the subg. & 50 & 50 & 10 & 0 & - \\
\hline Relaps/progression $(\mathrm{N})$ & 2 & 3 & 5 & 1 & 0 \\
\hline$\%$ of p. with relaps/progression out of all p. with tr. in the subg. & 100 & 75 & 50 & 100 & - \\
\hline Median TTFP (m.) & 40 & 24 & 23 & 20 & - \\
\hline $\operatorname{Died}(\mathrm{N})$ & 1 & 2 & 0 & 0 & 0 \\
\hline$\%$ of p. died out of all p. in the subg. & 25 & 50 & 0 & 0 & 0 \\
\hline Died - median survival (m.) & 44 & 60 & - & - & - \\
\hline Died for CLL (N) & 1 & 0 & 0 & 0 & 0 \\
\hline$\%$ of p. died for CLL out of all p. in the subg. & 25 & 0 & 0 & 0 & 0 \\
\hline
\end{tabular}

Abbreviations: CR, complete remission; dg., diagnosis; m., months; p., patients; PR, partial remission; subg., subgroup; tr., treatment; TTFP, time to first relaps/progression; TTFT, time to first treatment; y., years 
Table S3. Characteristics of cytogenetic subgroups based on the presence of certain abnormalities and karyotype complexity - patients with two abnormalities.

\begin{tabular}{|c|c|c|c|c|c|c|}
\hline Patients in subgroups & $\begin{array}{c}\text { Two incl } \\
14 q 32 \text { rear }\end{array}$ & $\begin{array}{l}\operatorname{Del}(13 q)+ \\
\text { trisomy } 12\end{array}$ & $\begin{array}{l}\text { Two incl } \\
\text { del }(17 p)\end{array}$ & $\begin{array}{c}\text { Del(13q) + } \\
\text { other abn }\end{array}$ & $\begin{array}{l}\text { Bialellic } \\
\text { del(13q) }\end{array}$ & $\begin{array}{c}\operatorname{Del}(13 q)+ \\
\operatorname{del}(11 q)\end{array}$ \\
\hline $\mathrm{N}$ & 5 & 4 & 1 & 7 & 6 & 5 \\
\hline$\%$ of all & 18 & 14 & 4 & 25 & 21 & 18 \\
\hline Males (N) & 4 & 3 & 1 & 5 & 3 & 5 \\
\hline Females $(\mathrm{N})$ & 1 & 1 & 0 & 2 & 3 & 0 \\
\hline Median age at dg. (y.) & 57 & 64 & 70 & 62 & 62 & 63 \\
\hline Treatment for other malignancy $(\mathrm{N})$ & 0 & 0 & 0 & 0 & 0 & 0 \\
\hline Rai 0 status (N) & 1 & 1 & 0 & 3 & 5 & 1 \\
\hline Rai 1 & 4 & 2 & 1 & 3 & 0 & 4 \\
\hline Rai 2 & 0 & 1 & 0 & 1 & 1 & 0 \\
\hline Median follow-up (m.) & 48 & 49 & 59 & 60 & 92 & 74 \\
\hline Treatment for CLL (N) & 1 & 2 & 1 & 4 & 4 & 5 \\
\hline$\%$ of p. with treatment out of all p. in the subg. & 20 & 50 & 100 & 57 & 67 & 100 \\
\hline Median TTFT (m.) & 3 & 9 & 13 & 13 & 18 & 26 \\
\hline Treatment started in less than $2 \mathrm{y}$. after dg. $(\mathrm{N})$ & 1 & 2 & 1 & 3 & 3 & 2 \\
\hline$\%$ of p. with tr. in less than 2 y. out of all p. in the subg. & 20 & 50 & 100 & 43 & 50 & 40 \\
\hline $\mathrm{CR}$ after 1. line therapy $(\mathrm{N})$ & 1 & 1 & 0 & 4 & 3 & 4 \\
\hline$\%$ of p. with CR out of all p. with tr. in the subg. & 100 & 50 & $\mathbf{0}$ & 100 & 75 & 80 \\
\hline PR after 1 . line therapy $(\mathrm{N})$ & 0 & 1 & 1 & 0 & 1 & 1 \\
\hline$\%$ of p. with PR out of all p. with tr. in the subg. & 0 & 50 & 100 & 0 & 25 & 20 \\
\hline Relaps/progression $(\mathrm{N})$ & 1 & 2 & 1 & 3 & 1 & 3 \\
\hline$\%$ of p. with relaps/progression out of all p. with tr. in the subg. & 100 & 100 & 100 & 75 & 25 & 60 \\
\hline Median TTFP (m.) & 74 & 15 & 33 & 24 & 34 & 15 \\
\hline $\operatorname{Died}(\mathrm{N})$ & 0 & 1 & 1 & 1 & 0 & 0 \\
\hline$\%$ of $p$. died out of all $p$. in the subg. & $\mathbf{0}$ & 25 & 100 & 14 & $\mathbf{0}$ & $\mathbf{0}$ \\
\hline Died - median survival (m.) & - & 44 & 59 & 60 & - & - \\
\hline Died for CLL (N) & 0 & 1 & 0 & 0 & 0 & 0 \\
\hline$\%$ of p. died for CLL out of all p. in the subg. & 0 & 25 & 0 & 0 & 0 & 0 \\
\hline
\end{tabular}

Abbreviations: abn, abnormality; CR, complete remission; dg., diagnosis; incl, including; m., months; p., patients; PR, partial remission; rear, rearangement; subg., subgroup; tr., treatment; TTFP, time to first relaps/progression; TTFT, time to first treatment; y., years 
Table S4. Characteristics of cytogenetic subgroups based on the determination of primary abnormalities - complex karyotypes.

\begin{tabular}{|c|c|c|c|c|c|c|}
\hline Patients in subgroups & $\operatorname{Del}(11 q)$ & $\operatorname{Del}(17 p)$ & $\operatorname{Del}(13 q)$ & Ambiguous & Trisomy 12 & Other abn \\
\hline $\mathrm{N}$ & 6 & 3 & 9 & 3 & 3 & 3 \\
\hline$\%$ of all & 22 & 11 & 33 & 11 & 11 & 11 \\
\hline Males (N) & 3 & 3 & 5 & 2 & 0 & 0 \\
\hline Females $(\mathrm{N})$ & 3 & 0 & 4 & 1 & 3 & 3 \\
\hline Median age at dg. (y.) & 68 & 60 & 67 & 58 & 61 & 66 \\
\hline Treatment for other malignancy $(\mathrm{N})$ & 0 & 0 & 0 & 0 & 0 & 0 \\
\hline Rai 0 status (N) & 0 & 0 & 0 & 1 & 2 & 1 \\
\hline Rai 1 & 2 & 3 & 5 & 1 & 1 & 2 \\
\hline Rai 2 & 4 & 0 & 4 & 1 & 0 & 0 \\
\hline Median follow-up (m.) & 50 & 35 & 66 & 68 & 79 & 49 \\
\hline Treatment for CLL (N) & 6 & 3 & 8 & 3 & 2 & 2 \\
\hline$\%$ of p. with treatment out of all p. in the subg. & 100 & 100 & 89 & 100 & 67 & 67 \\
\hline Median TTFT (m.) & 3 & 4 & 5 & 11 & 14 & 17 \\
\hline Treatment started in less than $2 \mathrm{y}$. after dg. $(\mathrm{N})$ & 5 & 3 & 7 & 2 & 2 & 1 \\
\hline$\%$ of p. with tr. in less than $2 \mathrm{y}$. out of all p. in the subg. & 83 & 100 & 78 & 67 & 67 & 33 \\
\hline CR after 1 . line therapy $(\mathrm{N})$ & 6 & 1 & 6 & 3 & 1 & 0 \\
\hline$\%$ of p. with CR out of all p. with tr. in the subg. & 100 & 33 & 75 & 100 & 50 & $\mathbf{0}$ \\
\hline PR after 1. line therapy $(\mathrm{N})$ & 0 & 1 & 2 & 0 & 1 & 2 \\
\hline$\%$ of p. with PR out of all p. with tr. in the subg. & 0 & 33 & 25 & 0 & 50 & 100 \\
\hline Relaps/progression (N) & 4 & 2 & 5 & 2 & 1 & 1 \\
\hline$\%$ of p. with relaps/progression out of all p. with tr. in the subg. & 67 & 67 & 63 & 67 & 50 & 50 \\
\hline Median TTFP (m.) & 24 & 21 & 29 & 21 & 48 & 9 \\
\hline $\operatorname{Died}(\mathrm{N})$ & 2 & 3 & 1 & 2 & 0 & 0 \\
\hline$\%$ of p. died out of all p. in the subg. & 33 & 100 & 11 & 67 & 0 & $\mathbf{0}$ \\
\hline Died - median survival (m.) & 41 & 35 & 4 & 67 & - & - \\
\hline Died for CLL (N) & 1 & 2 & 0 & 0 & 0 & 0 \\
\hline$\%$ of p. died for CLL out of all p. in the subg. & 17 & 67 & 0 & 0 & 0 & 0 \\
\hline
\end{tabular}

Abbreviations: CR, complete remission; dg., diagnosis; m., months; p., patients; PR, partial remission; subg., subgroup; tr., treatment; TTFP, time to first relaps/progression; TTFT, time to first treatment; y., years 
Table S5. Characteristics of subgroups based on the presence of certain abnormalities or complexity - complex karyotypes.

\begin{tabular}{|c|c|c|c|c|c|c|}
\hline \multirow[b]{2}{*}{ Patients in subgroups } & \multicolumn{3}{|c|}{ variant 1} & \multicolumn{3}{|c|}{ variant 2} \\
\hline & $\begin{array}{l}\text { Compl kar } \\
\text { incl del }(17 p)\end{array}$ & $\begin{array}{c}\text { Compl kar incl } \\
\text { del(11q) without } \\
\text { del(17p) }\end{array}$ & $\begin{array}{l}\text { Compl kar without } \\
\operatorname{del}(11 q) \text { or } \operatorname{del}(17 p)\end{array}$ & $\begin{array}{c}\text { Four abn } \\
\text { overall }\end{array}$ & $\begin{array}{l}\text { Min five abn } \\
\text { overall }\end{array}$ & $\begin{array}{c}\text { Three abn } \\
\text { overall }\end{array}$ \\
\hline $\mathrm{N}$ & 6 & 13 & 8 & 4 & 10 & 13 \\
\hline$\%$ of all & 22 & 48 & 30 & 15 & 37 & 48 \\
\hline Males (N) & 5 & 6 & 2 & 2 & 5 & 6 \\
\hline Females $(\mathrm{N})$ & 1 & 7 & 6 & 2 & 5 & 7 \\
\hline Median age at dg. (y.) & 67 & 66 & 60 & 68 & 64 & 64 \\
\hline Treatment for other malignancy (N) & 0 & 0 & 0 & 0 & 0 & 0 \\
\hline Rai 0 status $(\mathrm{N})$ & 0 & 0 & 4 & 1 & 0 & 3 \\
\hline Rai 1 & 5 & 7 & 2 & 1 & 7 & 6 \\
\hline Rai 2 & 1 & 6 & 2 & 2 & 3 & 4 \\
\hline Median follow-up (m.) & 35 & 66 & 68 & 59 & 42 & 73 \\
\hline Treatment for CLL (N) & 5 & 13 & 6 & 4 & 9 & 11 \\
\hline $\begin{array}{l}\% \text { of } \mathrm{p} \text {. with treatment out of all p. in } \\
\text { the subg. }\end{array}$ & 83 & 100 & 75 & 100 & 90 & 85 \\
\hline Median TTFT (m.) & 4 & 5 & 10 & 3 & 6 & 11 \\
\hline $\begin{array}{l}\text { Treatment started in less than } 2 \mathrm{y} \text {. } \\
\text { after dg. }(\mathrm{N})\end{array}$ & 5 & 10 & 5 & 3 & 8 & 9 \\
\hline $\begin{array}{l}\% \text { of p. with tr. in less than } 2 \mathrm{y} \text {. out } \\
\text { of all p. in the subg. }\end{array}$ & 83 & 77 & 63 & 75 & 80 & 69 \\
\hline $\mathrm{CR}$ after 1 . line therapy $(\mathrm{N})$ & 1 & 11 & 5 & 3 & 4 & 10 \\
\hline $\begin{array}{l}\% \text { of } p \text {. with CR out of all p. with tr. } \\
\text { in the subg. }\end{array}$ & 20 & 85 & 83 & 75 & 44 & 91 \\
\hline PR after 1. line therapy $(\mathrm{N})$ & 3 & 2 & 1 & 1 & 4 & 1 \\
\hline $\begin{array}{l}\% \text { of p. with PR out of all p. with tr. } \\
\text { in the subg. }\end{array}$ & 60 & 15 & 17 & 25 & 44 & 9 \\
\hline Relaps/progression (N) & 2 & 9 & 4 & 3 & 4 & 8 \\
\hline $\begin{array}{l}\% \text { of p. with relaps/progression out of } \\
\text { all p. with tr. in the subg. }\end{array}$ & 40 & 69 & 67 & 75 & 44 & 73 \\
\hline Median TTFP (m.) & 21 & 29 & 35 & 18 & 16 & 29 \\
\hline $\operatorname{Died}(\mathrm{N})$ & 4 & 3 & 1 & 1 & 5 & 2 \\
\hline$\%$ of p. died out of all p. in the subg. & 67 & 23 & 13 & 25 & 50 & 15 \\
\hline Died - median survival (m.) & 21 & 51 & 57 & 51 & 31 & 56 \\
\hline Died for CLL $(\mathrm{N})$ & 2 & 1 & 0 & 1 & 1 & 1 \\
\hline $\begin{array}{l}\% \text { of p. died for CLL out of all p. in } \\
\text { the subg. }\end{array}$ & 33 & 8 & 0 & 25 & 10 & 8 \\
\hline
\end{tabular}

Abbreviations: abn, abnormality; compl, complex; CR, complete remission; dg., diagnosis; incl, including; kar, karyotype; m., months; p., patients; PR, partial remission; rear, rearangement; subg., subgroup; tr., treatment; TTFP, time to first relaps/progression; TTFT, time to first treatment; y., years 
Table S1: Summary of all laboratory and clinical data for the study cohort of $121 \mathrm{CLL}$ patients

\begin{tabular}{|c|c|c|c|c|c|c|c|c|c|c|c|c|c|c|c|}
\hline ID & Gender (M/F) & $\begin{array}{l}\text { Age } \\
\text { at dg. } \\
\text { (y.) }\end{array}$ & Date of $\mathrm{dg}$. & $\begin{array}{c}\text { Tr. for } \\
\text { other } \\
\text { mal. } \\
\text { (Yes/No) }\end{array}$ & $\begin{array}{l}\text { Date } \\
\text { and tr. } \\
\text { for } \\
\text { other } \\
\text { mal. }\end{array}$ & $\begin{array}{l}\text { Rai } \\
\text { stage } \\
\text { at dg. }\end{array}$ & $\begin{array}{l}\text { Time } \\
\text { from dg. } \\
\text { to CLL tr. } \\
\text { start (m.) }\end{array}$ & $\begin{array}{l}\text { Type of } 1 . \\
\text { line tr. }\end{array}$ & $\begin{array}{c}\text { Type of } \\
\text { rem. }\end{array}$ & $\begin{array}{c}\text { Relaps/pro } \\
\text { g. } \\
\text { (Yes/No) }\end{array}$ & $\begin{array}{l}\text { Time to } \\
1 . \\
\text { relaps/p } \\
\text { rog. } \\
\text { (m.) }\end{array}$ & $\begin{array}{c}\text { Present } \\
\text { status } \\
\text { (A/D) }\end{array}$ & $\begin{array}{l}\text { Time of } \\
\text { f.-up } \\
\text { (m.) }\end{array}$ & $\begin{array}{c}\text { Surviv } \\
\text { al } \\
\text { time } \\
\text { from } \\
\text { dg. } \\
\text { (m.) }\end{array}$ & $\begin{array}{c}\text { Cause } \\
\text { of } \\
\text { death } \\
\text { (CLL/Ot } \\
\text { her) }\end{array}$ \\
\hline 1 & $M$ & 62 & 1.5 .2008 & $\mathrm{~N}$ & & 1 & 10 & R-FC & $C R$ & $\mathrm{~N}$ & & A & 103 & & \\
\hline 2 & $\mathrm{~F}$ & 69 & 1.4 .2008 & $\mathrm{~N}$ & & 2 & 2 & $\begin{array}{l}\mathrm{R}-\mathrm{CHOP}, \\
\text { mono } \\
\text { rituximab }\end{array}$ & PR & $\mathrm{Y}$ & 42 & A & 104 & & \\
\hline 8 & M & 61 & 1.7 .2008 & $N$ & & 0 & & without tr. & & & & A & 100 & & \\
\hline 9 & M & 56 & 1.7 .2008 & $\mathrm{~N}$ & & 1 & 89 & R-FC & $C R$ & $\mathrm{~N}$ & & A & 100 & & \\
\hline 10 & $\mathrm{~F}$ & 50 & 1.9 .2008 & $N$ & & 0 & & without tr. & & & & A & 98 & & \\
\hline 14 & M & 66 & 1.11 .2008 & $N$ & & 2 & 3 & $\begin{array}{c}\text { R-CHOP, } \\
\text { mono } \\
\text { rituximab }\end{array}$ & CR & & 75 & A & 96 & & \\
\hline 15 & M & 61 & 1.11 .2008 & $N$ & & 0 & 40 & R-FC & CR & $Y$ & 19 & A & 96 & & \\
\hline 20 & M & 48 & 1.12 .2008 & $N$ & & 0 & & without tr. & & & & A & 95 & & \\
\hline 22 & M & 52 & 1.4 .2009 & $N$ & & 2 & 10 & $\begin{array}{c}\mathrm{R}-\mathrm{FC} \\
\text { mono } \\
\text { rituximab }\end{array}$ & $C R$ & $\mathrm{Y}$ & 34 & A & 91 & & \\
\hline 23 & $\mathrm{~F}$ & 64 & 1.3 .2009 & $\mathrm{~N}$ & & 0 & 14 & $\begin{array}{c}\mathrm{R}-\mathrm{FC} \\
\text { mono } \\
\text { rituximab }\end{array}$ & PR & $\mathrm{N}$ & & A & 92 & & \\
\hline
\end{tabular}




\begin{tabular}{|c|c|c|c|c|c|c|c|c|c|c|c|c|c|c|}
\hline 40 & $M$ & 79 & 1.1 .2008 & $N$ & 1 & & without tr. & & & & A & 88 & & \\
\hline 44 & $M$ & 61 & 1.1 .2010 & $N$ & 0 & 20 & $\mathrm{R}-\mathrm{FC}$ & $\mathrm{CR}$ & $Y$ & 56 & A & 82 & & \\
\hline 46 & $\mathrm{~F}$ & 68 & 1.1 .2008 & $\mathrm{~N}$ & 1 & 26 & $\begin{array}{c}\text { R-COP, } \\
\text { mono } \\
\text { rituximab }\end{array}$ & $C R$ & $\mathrm{~N}$ & & A & 107 & & \\
\hline 53 & $M$ & 46 & 1.6.2010 & $\mathrm{N}$ & 2 & 1 & $\mathrm{R}-\mathrm{FC}$ & $\mathrm{CR}$ & $Y$ & 30 & A & 77 & & \\
\hline 55 & $\mathrm{~F}$ & 62 & 1.6.2010 & $N$ & 0 & & without tr. & & & & A & 77 & & \\
\hline 56 & M & 65 & 1.6 .2010 & $\mathrm{~N}$ & 2 & 2 & $\mathrm{R}-\mathrm{FC}$ & $C R$ & $\mathrm{~N}$ & & A & 77 & & \\
\hline 57 & $M$ & 56 & 1.6.2010 & $\mathrm{N}$ & 0 & 49 & $\mathrm{R}-\mathrm{FC}$ & $\mathrm{CR}$ & $N$ & & A & 77 & & \\
\hline 58 & $\mathrm{~F}$ & 56 & 1.3.2010 & $\mathrm{N}$ & 2 & 4 & $\begin{array}{c}\mathrm{R}-\mathrm{FC} \\
\text { mono } \\
\text { rituximab }\end{array}$ & PR & $\mathrm{Y}$ & 19 & A & 80 & & \\
\hline 59 & M & 61 & 1.1.2005 & $\mathrm{N}$ & 1 & 62 & $\begin{array}{l}\text { Leukeran, } \\
\text { Prednison }\end{array}$ & $C R$ & $\mathrm{~N}$ & & D & 102 & 102 & $\begin{array}{c}\text { ca. } \\
\text { generali } \\
\text { zation }\end{array}$ \\
\hline 61 & $M$ & 63 & 1.5.2010 & $\mathrm{N}$ & 1 & 28 & $\mathrm{FC}, \mathrm{R}-\mathrm{FC}$ & $\mathrm{CR}$ & $Y$ & 22 & A & 78 & & lung ca. \\
\hline 64 & M & 64 & 1.9.2010 & $\mathrm{N}$ & 0 & 49 & $\begin{array}{l}\text { Levact, } \\
\text { idealisib/pl } \\
\text { acebo }\end{array}$ & $\mathrm{CR}$ & $Y$ & 15 & A & 74 & & \\
\hline 75 & $\mathrm{~F}$ & 62 & 1.1 .2011 & $N$ & 0 & 27 & $\mathrm{R}-\mathrm{FC}$ & $\mathrm{CR}$ & $N$ & & A & 70 & & \\
\hline 79 & $M$ & 59 & 1.6.2011 & $\mathrm{N}$ & 0 & & without tr. & & & & A & 65 & & \\
\hline 81 & $\mathrm{~F}$ & 62 & 1.5.2011 & $\mathrm{N}$ & 1 & 5 & $\mathrm{R}-\mathrm{FC}$ & $\mathrm{CR}$ & $Y$ & 29 & A & 66 & & \\
\hline 83 & $\mathrm{~F}$ & 77 & 1.6.2011 & $N$ & 1 & 5 & $\mathrm{R}-\mathrm{FC}$ & $\mathrm{CR}$ & $Y$ & 24 & A & 48 & & \\
\hline 84 & $\mathrm{~F}$ & 55 & 1.7.2011 & $N$ & 1 & & without tr. & & & & A & 64 & & \\
\hline 95 & $\mathrm{~F}$ & 48 & 1.10 .2011 & $\mathrm{~N}$ & 1 & 57 & $\mathrm{R}-\mathrm{FC}$ & $\mathrm{CR}$ & $\mathrm{N}$ & & A & 61 & & \\
\hline 96 & M & 73 & 1.5.2011 & $\mathrm{N}$ & 2 & 7 & $\mathrm{R}-\mathrm{FC}$ & $\mathrm{CR}$ & $\mathrm{Y}$ & 57 & A & 66 & & \\
\hline 97 & $\mathrm{M}$ & 66 & 1.10.2011 & $\mathrm{N}$ & 2 & 12 & $\mathrm{R}-\mathrm{CHOP}$ & $\mathrm{CR}$ & $\mathrm{Y}$ & 23 & A & 61 & & \\
\hline 102 & $\mathrm{M}$ & 60 & 1.2.2010 & $\mathrm{N}$ & 1 & 53 & $\mathrm{R}-\mathrm{FC}$ & $\mathrm{CR}$ & $\mathrm{Y}$ & 17 & A & 81 & & \\
\hline 109 & $\mathrm{~F}$ & 71 & 1.4.2012 & $N$ & 1 & 4 & $\mathrm{R}-\mathrm{FC}$ & $\mathrm{CR}$ & $Y$ & 23 & A & 55 & & \\
\hline 113 & $M$ & 73 & 1.4.2012 & $\mathrm{N}$ & 1 & & without tr. & & & & A & 55 & & \\
\hline 115 & M & 69 & 1.8 .2012 & $\mathrm{~N}$ & 0 & 15 & $\begin{array}{c}\text { chlorambu } \\
\text { cil }\end{array}$ & $C R$ & $\mathrm{~N}$ & & A & 51 & & \\
\hline 117 & $M$ & 64 & 1.8 .2012 & $\mathrm{~N}$ & 1 & 6 & $\mathrm{R}-\mathrm{FC}$ & $C R$ & $\mathrm{~N}$ & & A & 51 & & \\
\hline
\end{tabular}




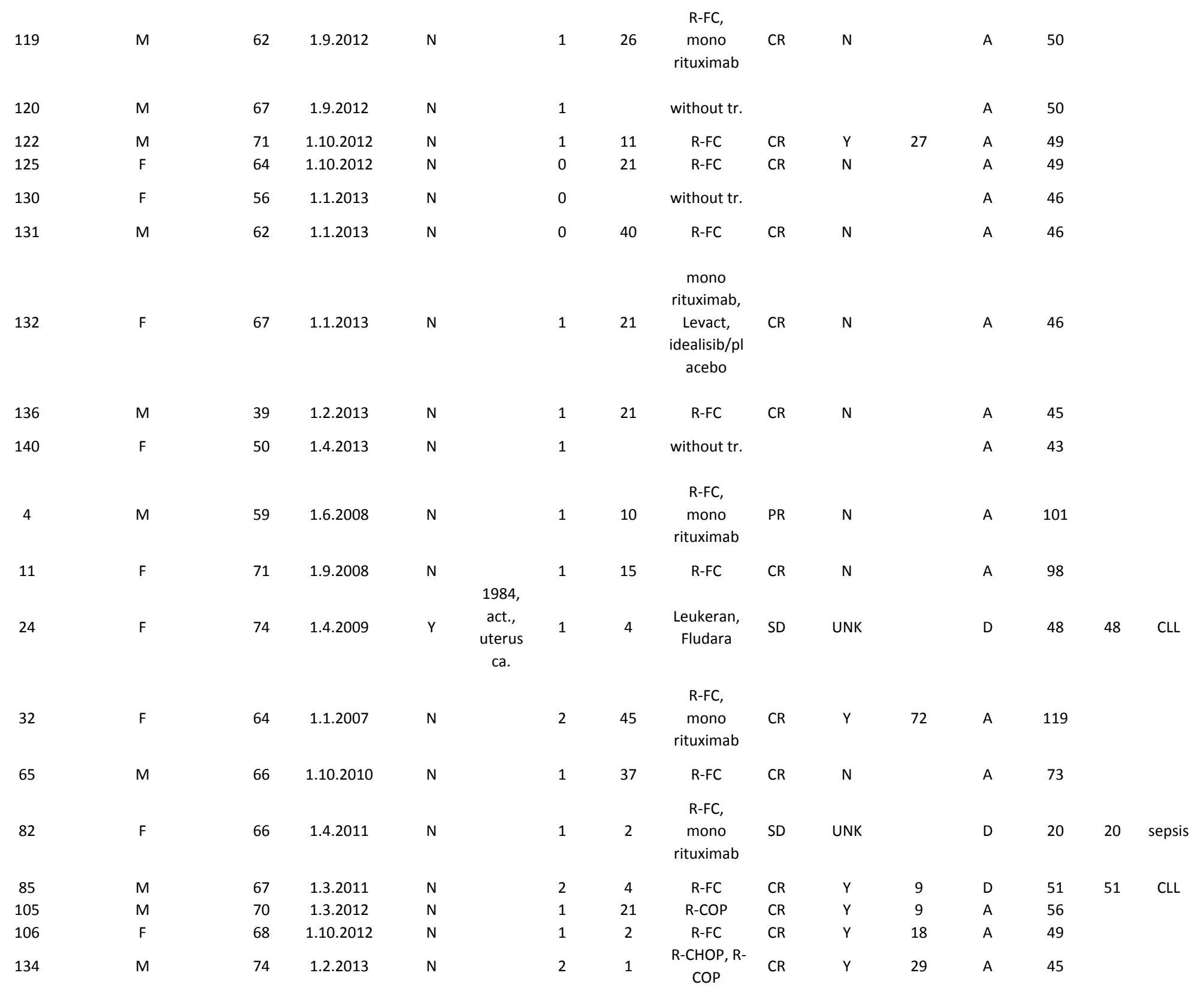




\begin{tabular}{|c|c|c|c|c|c|c|c|c|c|c|c|c|c|c|c|}
\hline 142 & $\mathrm{M}$ & 53 & 1.6 .2013 & $\mathrm{~N}$ & & 2 & 1 & $\begin{array}{c}\mathrm{R}-\mathrm{FC} \\
\text { mono } \\
\text { rituximab }\end{array}$ & $C R$ & UNK & & $\mathrm{D}$ & 31 & 31 & sepsis \\
\hline 16 & $M$ & 70 & 1.9 .2008 & $\mathrm{~N}$ & & 1 & 3 & $\begin{array}{l}\text { R-CHOP, } \\
\text { mono } \\
\text { rituximab }\end{array}$ & $C R$ & Y & 74 & A & 98 & & \\
\hline 17 & $\mathrm{~F}$ & 61 & 1.1 .2009 & $N$ & & 0 & & without tr. & & & & $A$ & 94 & & \\
\hline 19 & $M$ & 67 & 1.6 .2008 & $N$ & & 0 & 43 & $\mathrm{R}-\mathrm{CHOP}$ & $C R$ & Y & 30 & $\mathrm{D}$ & 76 & 76 & CLL \\
\hline 33 & $M$ & 48 & 1.9.2009 & $N$ & & 0 & & without tr. & & & & $A$ & 86 & & \\
\hline 41 & $M$ & 67 & 1.1.2007 & $\mathrm{N}$ & & 1 & 30 & $\begin{array}{l}\text { chlorambu } \\
\text { cil, R-FC }\end{array}$ & $\mathrm{CR}$ & $\mathrm{N}$ & & A & 119 & & \\
\hline 45 & $\mathrm{M}$ & 33 & 1.1 .2010 & $\mathrm{~N}$ & & 1 & 8 & $\begin{array}{c}\mathrm{R}-\mathrm{FC} \\
\text { mono } \\
\text { rituximab }\end{array}$ & PR & Y & 21 & D & 65 & 65 & sepsis \\
\hline 48 & $\mathrm{~F}$ & 70 & 1.4 .2010 & $\mathrm{~N}$ & & 1 & 16 & $\begin{array}{c}\text { R-FC, } \\
\text { mono } \\
\text { rituximab }\end{array}$ & $C R$ & $\mathrm{~N}$ & & A & 79 & & \\
\hline 49 & $\mathrm{~F}$ & 50 & 1.4.2010 & $\mathrm{N}$ & & 1 & 51 & $\mathrm{R}-\mathrm{FC}$ & $C R$ & Y & 24 & A & 79 & & \\
\hline 51 & $M$ & 61 & 1.5 .2010 & $\mathrm{~N}$ & & 1 & 6 & $\mathrm{R}-\mathrm{COP}$ & $P R$ & Y & 6 & $\mathrm{D}$ & 44 & 44 & CLL \\
\hline 68 & $\mathrm{~F}$ & 59 & 1.10 .2010 & $N$ & & 0 & 12 & $\mathrm{R}-\mathrm{FC}$ & $P R$ & Y & 48 & $A$ & 73 & & \\
\hline 99 & $\mathrm{~F}$ & 61 & 1.12 .2011 & $\mathrm{Y}$ & $\begin{array}{c}2004, \\
\text { rad., } \\
\text { hor. tr., } \\
\text { breast } \\
\text { ca. }\end{array}$ & 1 & & without tr. & & & & A & 59 & & \\
\hline 129 & $\mathrm{~F}$ & 62 & 1.1 .2013 & $N$ & & 0 & & without tr. & & & & A & 46 & & \\
\hline 135 & $\mathrm{~F}$ & 57 & 1.2 .2013 & $N$ & & 0 & & without tr. & & & & A & 45 & & \\
\hline 143 & $F$ & 64 & 1.6 .2013 & $N$ & & 0 & & without tr. & & & & A & 41 & & \\
\hline 144 & M & 57 & 1.7 .2013 & $\mathrm{~N}$ & & 1 & & without tr. & & & & A & 40 & & \\
\hline
\end{tabular}




\begin{tabular}{|c|c|c|c|c|c|c|c|c|c|c|c|c|c|c|}
\hline 3 & M & 70 & 1.5.2008 & $\mathrm{N}$ & 1 & 13 & $\begin{array}{c}\text { R-CHOP, } \\
\text { mono } \\
\text { rituximab }\end{array}$ & PR & $\mathrm{Y}$ & 33 & D & 59 & 59 & $\begin{array}{c}\text { pneum } \\
\text { onia }\end{array}$ \\
\hline 87 & M & 60 & 1.7.2011 & $\mathrm{N}$ & 1 & 13 & $\mathrm{R}-\mathrm{FC}$ & PR & $Y$ & 20 & D & 35 & 35 & $\begin{array}{l}\text { pneum } \\
\text { onia }\end{array}$ \\
\hline 89 & M & 60 & 1.3.2011 & $\mathrm{N}$ & 1 & 4 & $\begin{array}{c}\mathrm{R}-\mathrm{FC} \\
\text { mono } \\
\text { rituximab }\end{array}$ & CR & $\mathrm{Y}$ & 21 & D & 35 & 35 & CLL \\
\hline 138 & $\mathrm{M}$ & 72 & 1.3 .2013 & $\mathrm{~N}$ & 1 & 1 & $\mathrm{R}-\mathrm{FC}$ & SD & UNK & & $\mathrm{D}$ & 6 & 6 & CLL \\
\hline 38 & M & 65 & 1.10 .2009 & $\mathrm{~N}$ & 0 & 20 & $\mathrm{R}-\mathrm{FC}$ & PR & $\mathrm{Y}$ & 28 & A & 85 & & \\
\hline 69 & M & 60 & 1.11.2010 & $N$ & 1 & 1 & $\mathrm{R}-\mathrm{CHOP}$ & CR & $Y$ & 38 & $A$ & 72 & & \\
\hline 74 & $\mathrm{M}$ & 68 & 1.1.2011 & $\mathrm{N}$ & 2 & 1 & R-FC & CR & $\mathrm{Y}$ & 24 & D & 60 & 60 & sepsis \\
\hline 86 & M & 51 & 1.7.2011 & $N$ & 0 & 13 & $\mathrm{R}-\mathrm{FC}$ & CR & $Y$ & 46 & A & 64 & & \\
\hline 141 & $\mathrm{M}$ & 62 & 1.4 .2013 & $\mathrm{~N}$ & 1 & 17 & $\begin{array}{c}\text { mono } \\
\text { rituximab, } \\
\text { Levact, } \\
\text { idealisib/pl } \\
\text { acebo }\end{array}$ & CR & UNK & & A & 43 & & \\
\hline 5 & M & 70 & 1.5 .2008 & $\mathrm{~N}$ & 0 & & without tr. & & & & $\mathrm{D}$ & 44 & 44 & other \\
\hline 7 & M & 55 & 1.7.2008 & $N$ & 1 & & without tr. & & & & $A$ & 100 & & \\
\hline 13 & $\mathrm{~F}$ & 61 & 1.3.2007 & $\mathrm{N}$ & 0 & 40 & $\begin{array}{c}\mathrm{R}-\mathrm{FC}, \\
\text { mono } \\
\text { rituximab }\end{array}$ & PR & $\mathrm{Y}$ & 7 & D & 53 & 53 & CLL \\
\hline 43 & $\mathrm{M}$ & 69 & 1.12 .2009 & $\mathrm{~N}$ & 0 & 61 & $\begin{array}{c}\mathrm{R}-\mathrm{FC} \\
\text { mono } \\
\text { rituximab }\end{array}$ & CR & $\mathrm{N}$ & & A & 83 & & \\
\hline 47 & M & 62 & 1.1 .2010 & $\mathrm{~N}$ & 2 & 2 & $\begin{array}{c}\mathrm{R}-\mathrm{FC} \\
\text { mono } \\
\text { rituximab }\end{array}$ & CR & $\mathrm{N}$ & & A & 82 & & \\
\hline 50 & $\mathrm{~F}$ & 61 & 1.1.2010 & $\mathrm{N}$ & 1 & 3 & $\begin{array}{c}\text { FAMP, R- } \\
\text { CHOP }\end{array}$ & CR & $\mathrm{Y}$ & 23 & D & 50 & 50 & CLL \\
\hline 66 & $\mathrm{~F}$ & 66 & 1.9.2010 & $\mathrm{N}$ & 0 & 52 & $\mathrm{R}-\mathrm{FC}$ & PR & $\mathrm{Y}$ & 12 & A & 74 & & \\
\hline 76 & $\mathrm{M}$ & 60 & 1.1 .2008 & $\mathrm{~N}$ & 0 & 105 & $\mathrm{R}-\mathrm{FC}$ & UNK & $\mathrm{N}$ & & A & 107 & & \\
\hline
\end{tabular}




\begin{tabular}{|c|c|c|c|c|c|c|c|c|c|c|c|c|c|c|c|}
\hline 80 & $M$ & 60 & 1.6 .2011 & $N$ & & 1 & & without tr. & & & & A & 65 & & \\
\hline 94 & $M$ & 65 & 1.8 .2011 & $\mathrm{~N}$ & & 1 & & without tr. & & & & A & 63 & & \\
\hline 98 & M & 57 & 1.12 .2011 & $\mathrm{~N}$ & & 1 & 21 & $\mathrm{R}-\mathrm{CHOP}$ & $C R$ & $\mathrm{Y}$ & 18 & A & 59 & & \\
\hline 101 & M & 54 & 1.4 .2012 & $\mathrm{~N}$ & & 0 & & without tr. & & & & A & 55 & & \\
\hline 103 & M & 53 & 1.3.2012 & $\mathrm{N}$ & & 1 & 44 & $\begin{array}{c}\mathrm{R}-\mathrm{FC}, \\
\text { mono } \\
\text { rituximab }\end{array}$ & CR & $\mathrm{N}$ & & A & 56 & & \\
\hline 104 & $\mathrm{~F}$ & 57 & 1.2.2012 & $\mathrm{N}$ & & 1 & & without tr. & & & & A & 57 & & \\
\hline 112 & M & 59 & 1.6 .2012 & $\mathrm{~N}$ & & 0 & & without tr. & & & & A & 53 & & \\
\hline 116 & M & 70 & 1.8 .2012 & $\mathrm{~N}$ & & 2 & 26 & R-COP & PR & $\mathrm{N}$ & & A & 51 & & \\
\hline 123 & M & 65 & 1.10 .2012 & $\mathrm{~N}$ & & 1 & 1 & $\mathrm{R}-\mathrm{FC}$ & $C R$ & $\mathrm{Y}$ & 40 & A & 49 & & \\
\hline 126 & $\mathrm{~F}$ & 68 & 1.11 .2012 & $\mathrm{Y}$ & $\begin{array}{l}1999, \\
\text { rad., } \\
\text { hor. tr., } \\
\text { breast } \\
\text { ca. }\end{array}$ & 0 & & without tr. & & & & A & 48 & & \\
\hline 128 & $M$ & 75 & 1.1 .2013 & $\mathrm{~N}$ & & 0 & & without tr. & & & & A & 46 & & \\
\hline 145 & M & 66 & 1.7 .2013 & $\mathrm{~N}$ & & 1 & 11 & R-FC & CR & $\mathrm{N}$ & & A & 40 & & \\
\hline 18 & $\mathrm{~F}$ & 78 & 1.1.2009 & $\mathrm{N}$ & & 0 & 37 & $\begin{array}{l}\text { Leukeran, } \\
\text { COP }\end{array}$ & PR & $\mathrm{Y}$ & 13 & D & 76 & 76 & CLL \\
\hline 28 & M & 62 & 1.6.2009 & $N$ & & 0 & & without tr. & & & & A & 89 & & \\
\hline 42 & $M$ & 55 & 1.12 .2009 & $\mathrm{~N}$ & & 0 & 42 & $\mathrm{R}-\mathrm{FC}$ & $\mathrm{CR}$ & $Y$ & 20 & A & 83 & & \\
\hline 77 & $\mathrm{~F}$ & 47 & 1.4.2011 & $N$ & & 0 & & without tr. & & & & A & 67 & & \\
\hline 93 & $M$ & 51 & 1.9 .2011 & $N$ & & 2 & 1 & $\mathrm{R}-\mathrm{FC}$ & $P R$ & $Y$ & 40 & A & 62 & & \\
\hline 100 & $\mathrm{~F}$ & 56 & 1.1 .2012 & $N$ & & 0 & & without tr. & & & & A & 58 & & \\
\hline 110 & $\mathrm{~F}$ & 74 & 1.4.2012 & $\mathrm{N}$ & & 1 & 2 & $\mathrm{R}-\mathrm{COP}$ & $P R$ & $\mathrm{~N}$ & & A & 55 & & \\
\hline 121 & $\mathrm{~F}$ & 76 & 1.8 .2012 & $\mathrm{~N}$ & & 1 & 6 & R-COP & PR & $\mathrm{N}$ & & A & 35 & & \\
\hline 124 & $F$ & 66 & 1.10 .2012 & $\mathrm{~N}$ & & 1 & 27 & $\mathrm{R}-\mathrm{CHOP}$ & PR & $Y$ & 9 & A & 49 & & \\
\hline 127 & $M$ & 64 & 1.12 .2012 & $N$ & & 1 & & without tr. & & & & A & 47 & & \\
\hline 139 & M & 40 & 1.5 .2013 & $\mathrm{~N}$ & & 1 & & without tr. & & & & A & 42 & & \\
\hline
\end{tabular}




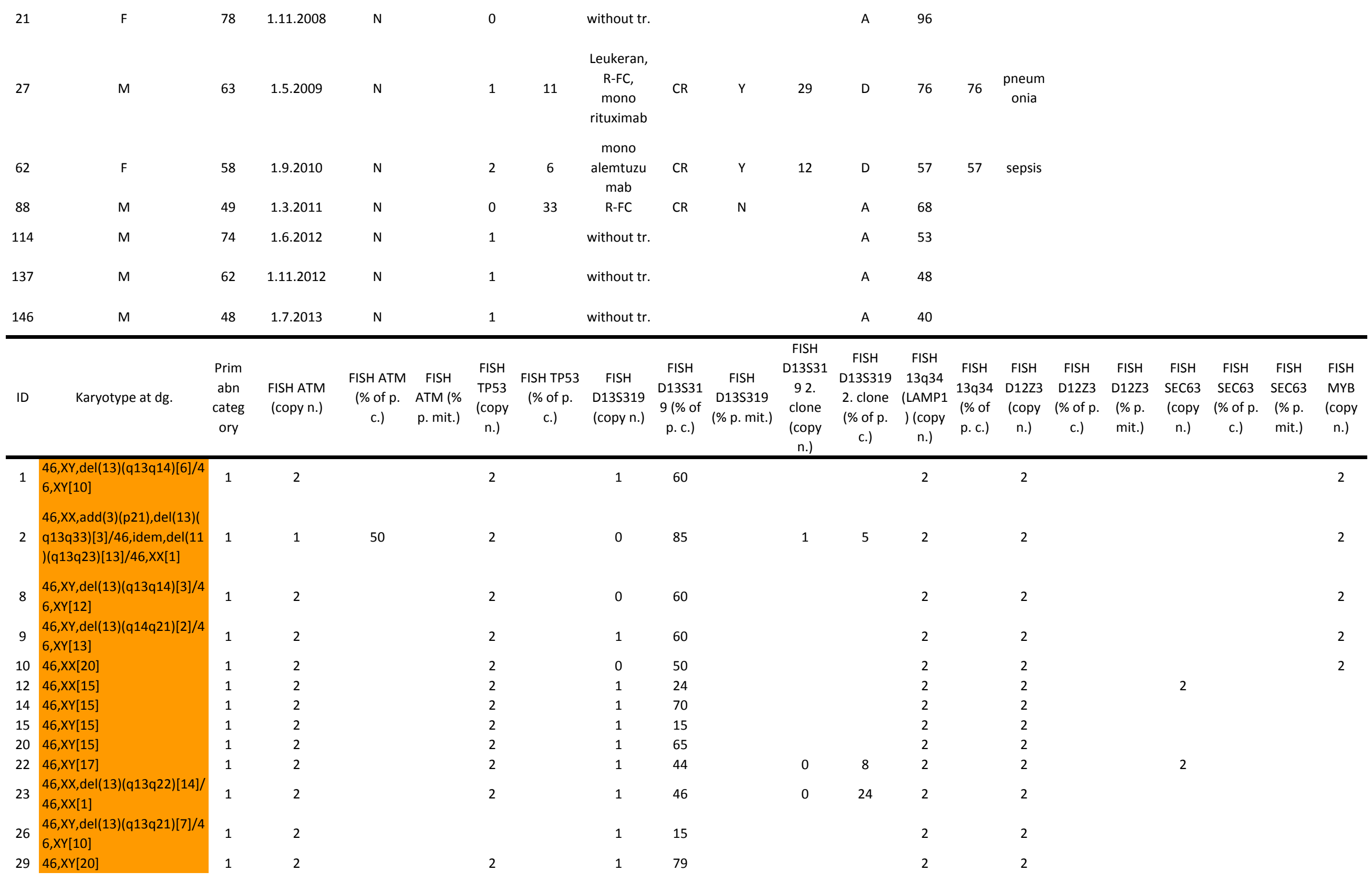


46,XY, add(6)(p21), der(9)t(6

;9)(p21;p13)del(9)(q13q22)

35 ,add(17)(p11.2),inc[1]46,id

em, $-2 \times 8,-9,-15,-18$,-

$21,+6 \operatorname{mar}, \operatorname{inc}[1] / 46, \mathrm{XY}[8]$

$46, X Y, \operatorname{der}(10) t(10 ; 13)(p 13 ;$

q14), $\operatorname{der}(13) t(10 ; 13)(p 13 ; q$

$13),+\operatorname{mar}[\mathrm{cp} 8] / 46, \mathrm{XY}, \mathrm{t}(7 ; ?)$

40 q11;?),der(10)t(10;13)(p13;

$q 14), \operatorname{der}(13) t(10 ; 13)(p 13 ; q$

13) $[\mathrm{cp} 8] / 46, \mathrm{XY}, \mathrm{t}(2 ; 18)(\mathrm{p} 12$

q22) $[\mathrm{cp} 5] / 46, X Y[3]$

$44 \quad 46, X Y[15]$

$646, X X, \operatorname{del}(13)(q 14 q 22)[15] /$

$46, X X[6]$

$46, X X$, add (8)(p1?1)[5]/46,X

$x[10]$

$5646, X Y[15]$

$5746, X X[19]$

$5846, X X[15]$

$5946, X Y[15]$

$6146, X Y$,add(?7)(qter)[4]/46,

$\mathrm{XY}[16]$

46,XY, del(11)(q21q24), del(

13)(q13q21)[14]/46,XY[6]

$7546, X X[20]$

$7946, X Y[15]$

$46, X X$, del(11)(q21q25),

$18, i(22)(q 10),+\operatorname{der}(?) t(18 ; ?)$

81 (q?12:?)[5]/45,idem, der(14

;?15)(q10;q10)[10]

$8346, X X, t(5 ; 9)(q 34 ; q 21)[20] \quad 1 \quad 2$

$9546, X X[15]$ 
$46, X Y, \operatorname{der}(18) t(2 ; 18)(p 11.2$

$46, X Y, \operatorname{del}(13)(q 13 q 31$

$9733)[2] / 47, X Y,+12[1] / 46, X Y[$

17]

$46, X Y, t(8 ; 14)(q 24 ; q 32)$, del(

$10211)(q 14 q 23)[10] / 46, X Y$, del(

13)(q14q31-

33) $[6] / 46, X Y[3]$

$10946, X X$, del(6)(q?13q22)[7]/4

$6, X X[13]$

$11346, X Y[20]$

$11546, X Y[20]$

$11746, X Y$,del(13)(q13q14)[9]/4 $6, X Y[11]$

$11946, X Y[15]$

$120 \quad 46, X Y[15]$

$12246, X Y[20]$

$12546, X X[20]$

$13046, X X[20]$

$13146, X Y[20]$

$13246, \mathrm{XX}$, del(11)(q21q23)[12]/ $46, X X[3]$

3646 ,XY, del(11)(q23),?del(13) (q13q21)[11]/46,XY[10]

$140 \quad 46, X X[12]$
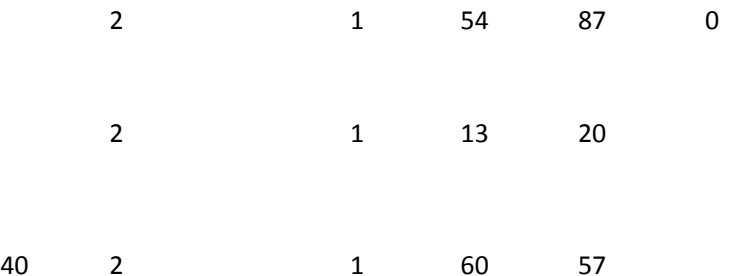

27
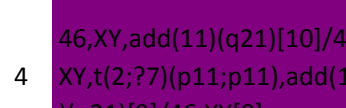

q21) $[9] / 46, X Y[8]$

$5, X X$, del(11)(q21q23)[4]

11

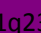

der(18)t(14:18)/a11:01

90

100

$0] / 46 \times x[3$

24

32

XX, del(11)(a21a22)!

2

2

2

2

40

20

65

99

100

$\begin{array}{ll}2 & 2 \\ 2 & 2 \\ 2 & 2\end{array}$




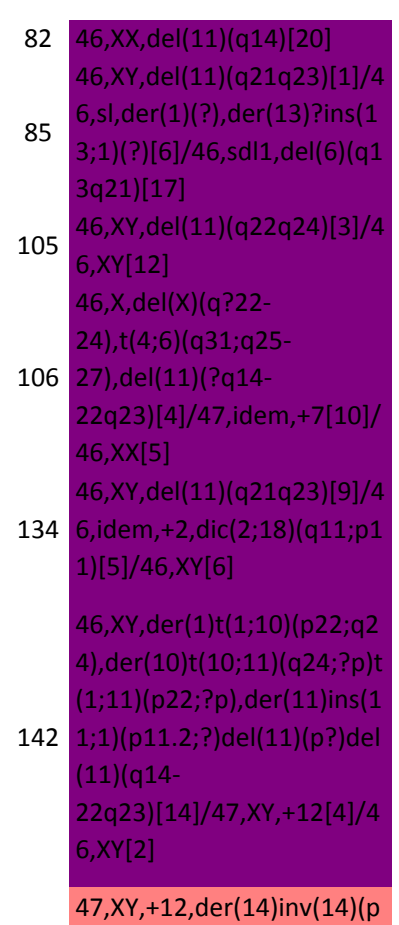

$11 q 32)$ del(14)(q12 21q31)[15]/46,XY[1]

$1746, x,-$

$x, t(2 ; 12)(q 24 ; p 13),+12[16]$

$1947, X Y,+12[7] / 46, X Y[13]$

$3347, X Y,+12[3] / 46, X Y[11]$

$4147, X Y,+12[20]$

$4547, X Y,+12[1] / 46, X Y[19]$ $46, X,-$

$48 \mathrm{X},+12[15] / 46$,idem, del(13)( q12q14)[5]

$4947, \mathrm{XX},+12[5] / 46, \mathrm{XX}[15]$

$47, X X,+12[10] / 47, X X,+12, d$ $\mathrm{el}(13)(q 13 q 22)[9] / 46, X X[1]$

$6847, \mathrm{XX},+12[8] / 47$, idem, dell 6)(?q21q25)[3]/46, XX[3]

80

2

7

0

11

2


$45, X Y$, der(3)t(3;17)(q2?7, q

11.2),-

$17[3] / 44, X Y, \operatorname{der}(3) t(3 ; 6)(q 2$ ?1,q14-16),-

$874, \operatorname{der}(6) t(6 ; 17)(q 14-$

$16 ; q 11.2), \operatorname{der}(13) t(3 ; 13)(q 2$

?1;p11)t(3;17)(q2?7,q11.2)

$17, \operatorname{der}(17) t(? 4 ; 17)(q 11.2 ; q$

12) $[5] / 46, X Y[3]$

$45, X Y, \operatorname{der}(6 ; 18)(p 10 ; q 10), d$ er(17)del(17)(p10)del(17)(q

892 ?2) [7]/44,XY, $\operatorname{der}(6 ; 18)(\mathrm{p} 1$

$0 ; q 10), \operatorname{der}(14 ; 17)(q 10 ; q 10)$

$[6] / 46, X Y[6]$

$46, X Y, ? \operatorname{add}(17)(\mathrm{p} 11.2)[6] / 4$

$6, s l$, del(6)(q?16q26)[4]/45,

sdl1,-

38 ,?der(17;21)(q10;q10),+m

$\operatorname{ar}[2] / 44, s l, a d d(3)(p 22-24)$,-

$16[4] / 46, s l$, del(11)(q22q23 )$[3] / 46, X Y[2]$

$38 \begin{aligned} & 46, X Y, \operatorname{del}(6)(q 13)[21] / 46, X \\ & Y[1]\end{aligned}$ $46, X Y$
$Y[1]$

5




\begin{tabular}{|c|c|c|c|c|c|c|c|c|c|c|c|}
\hline 74 & $46, \mathrm{XY}, \mathrm{del}(6)(\mathrm{q} 21 \mathrm{q} 25)[20]$ & 5 & 2 & & 2 & 1 & 76 & 67 & 2 & 2 & 1 \\
\hline 86 & $\begin{array}{l}46, X Y, \text { del(6)(q14- } \\
16, q 24)[2] / 46, X Y[18]\end{array}$ & 5 & 2 & & 2 & 2 & & & 2 & 2 & 1 \\
\hline 141 & $\begin{array}{l}46, X Y, \text { del(6)(q13q21)[4]/46 } \\
, X Y[15]\end{array}$ & 5 & 2 & & 2 & 2 & & & 2 & 2 & 1 \\
\hline 5 & $46, X Y[15]$ & 6 & 2 & & 2 & 2 & & & 2 & 2 & \\
\hline 7 & $46, X Y[15]$ & 6 & 2 & & 2 & 2 & & & 2 & 2 & \\
\hline 13 & $46, X x[20]$ & 6 & 2 & & 2 & 2 & & & 2 & 2 & \\
\hline 43 & $46, X Y[20]$ & 6 & 2 & & 2 & 2 & & & 2 & 2 & \\
\hline 47 & $46, X Y[17]$ & 6 & 2 & & 2 & 2 & & & 2 & 2 & \\
\hline 50 & $46, X X[15]$ & 6 & 2 & & 2 & 2 & & & 2 & 2 & \\
\hline 66 & $46, X x[15]$ & 6 & 2 & & 2 & 2 & & & 2 & 2 & 2 \\
\hline 76 & $46, X Y[15]$ & 6 & 2 & & 2 & 2 & & & 2 & 2 & 2 \\
\hline 80 & $\begin{array}{l}\text { 46,XY,del(11)(q?21)[5]/46, } \\
\text { XY[15] }\end{array}$ & 6 & 1 & 21 & 2 & 2 & & & 2 & 2 & \\
\hline 94 & $46, X Y[15]$ & 6 & 2 & & 2 & 2 & & & 2 & 2 & \\
\hline 98 & $46, X Y[20]$ & 6 & 2 & & 2 & 2 & & & 2 & 2 & 2 \\
\hline 101 & $46, X Y[15]$ & 6 & 2 & & 2 & 2 & & & 2 & 2 & 2 \\
\hline 103 & $46, X Y[15]$ & 6 & 2 & & 2 & 2 & & & 2 & 2 & 2 \\
\hline 104 & $46, X x[15]$ & 6 & 2 & & 2 & 1 & 36 & & 2 & 2 & \\
\hline 112 & $46, X Y[16]$ & 6 & 2 & & 2 & 2 & & & 2 & 2 & \\
\hline 116 & $46, X Y[20]$ & 6 & 2 & & 2 & 2 & & & 2 & 2 & 2 \\
\hline 123 & $46, X Y[15]$ & 6 & 2 & & 2 & 2 & & & 2 & 2 & 2 \\
\hline 126 & $46, X x[20]$ & 6 & 2 & & 2 & 1 & 10 & & 2 & 2 & 2 \\
\hline 128 & $46, \mathrm{XY}[9]$ & 6 & 2 & & 2 & 2 & & & 2 & 2 & \\
\hline 145 & $46, X Y[20]$ & 6 & 2 & & 2 & 2 & & & 2 & 2 & \\
\hline 18 & $\begin{array}{l}46, X X, \text { add }(5)(\text { pter)})[14] / 46, \\
X X[1]\end{array}$ & 7 & 2 & & 2 & 2 & & & 2 & 2 & \\
\hline 28 & $\begin{array}{l}46, X Y, t(2 ; 18)(p 12 ; q 22)[14] \\
/ 46, X Y[1]\end{array}$ & 7 & 2 & & 2 & 1 & 45 & 67 & 2 & 2 & \\
\hline 42 & $\begin{array}{l}46, X Y, \text { del(1)(q32q42)[13]/4 } \\
6, X Y[7] \\
48, X X, t(8 ; 14)(q 24 ; q 32),+2\end{array}$ & 7 & 2 & & 2 & 1 & 15 & 10 & 2 & 2 & \\
\hline 77 & $\begin{array}{l}\mathrm{mar}[7] / 48, \text { idem, del(14)(q2 } \\
\text { ?2q32)[13] }\end{array}$ & 7 & 2 & & 2 & 2 & & & 2 & 2 & \\
\hline 93 & $\begin{array}{l}46, X Y, t(14 ; 17)(q 24 ; q 25)[3] \\
/ 46, X Y[17]\end{array}$ & 7 & 2 & & 2 & 2 & & & 2 & 2 & 2 \\
\hline 100 & $\begin{array}{l}46, X X, t(11 ; 14)(q 13 ; q 32)[10 \\
] / 46, X X, \operatorname{del}(13)(q 12 q 21)[4]\end{array}$ & 7 & 2 & & 2 & 1 & 13 & & 2 & 2 & \\
\hline & $/ 46, \mathrm{XX}[6]$ & & & & & & & & & & \\
\hline 110 & $\begin{array}{l}\text { 46,XX,der(10)t(2;10)(?p12; } \\
\text { q26)[16]/46,XX[4] }\end{array}$ & 7 & 2 & & 2 & 2 & & & 2 & 2 & \\
\hline
\end{tabular}




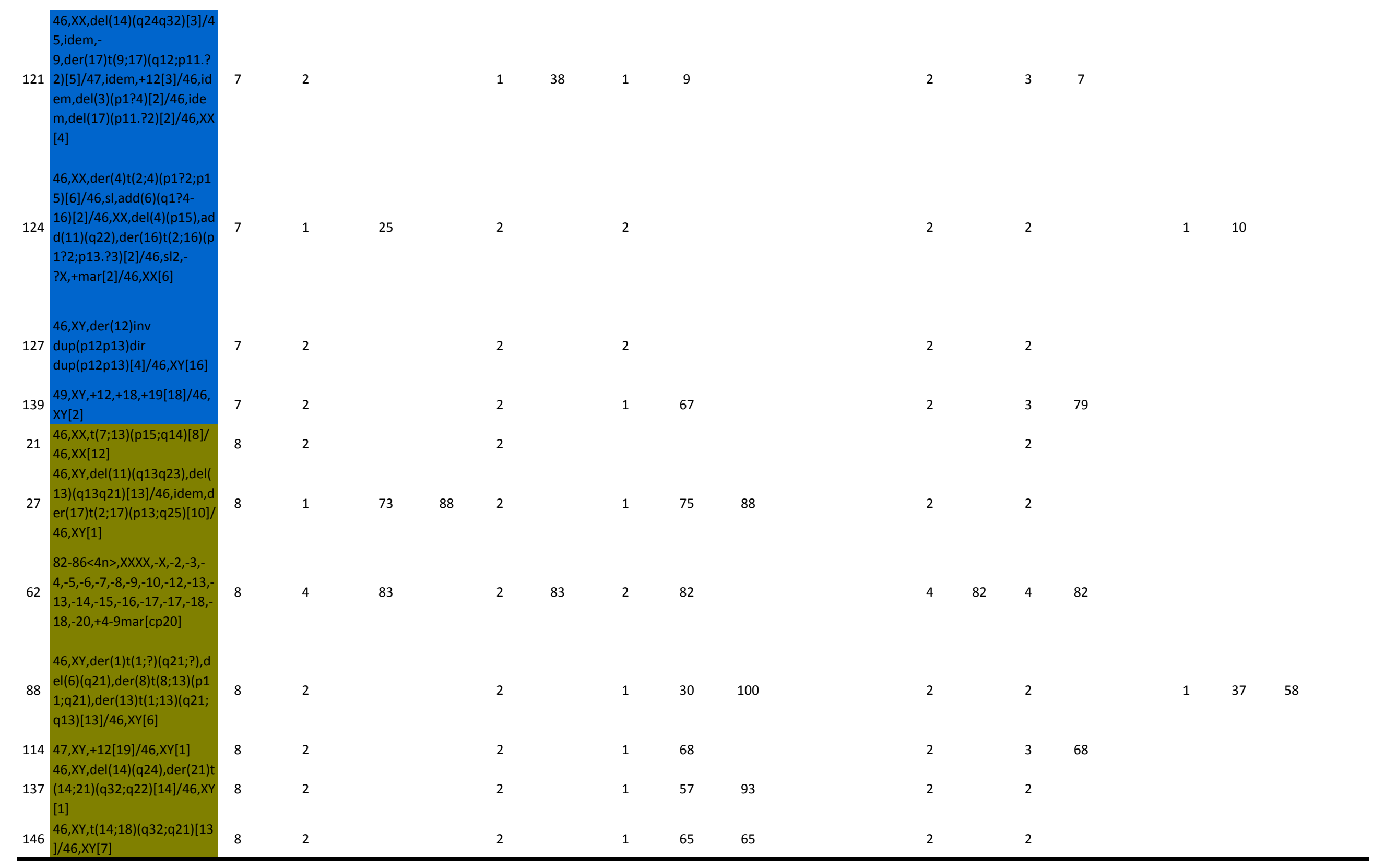


Abbreviations: A, alive; abn., abnormality; act., actinotherapy; c., cells; ca., carcinoma; CR, complete remission; D, deceased; dg., diagnosis; f., follow; hor., hormonal; m., months; mal., malignancy; mit., mitoses; mono., monotherapy; n., number; p., pathological; PR, partial remission; prim., primary; prog., progression; rad., radiotherapy; rem., remission; SD, stable disease; tr., treatment; UNK, unknown; $y$. , years
Prim. abn. category

\begin{tabular}{l|l}
1 & Deletion 13q14 \\
2 & Deletion 11q22/ATM \\
3 & Trisomy 12 \\
4 & Deletion 17p13/TP53 \\
5 & Deletion 6q \\
6 & Normal karyotype and FISH \\
7 & Other prim. abn. \\
8 & Ambiguous prim. abn.
\end{tabular}

